No $2004-05$

May

Does Exchange Rate Regime Explain Differences in Economic Results for Asian Countries ?

Virginie Coudert Marc Dubert 
Does Exchange Rate Regime Explain Differences in Economic Results for Asian Countries ?

Virginie Coudert Marc Dubert

No $2004-05$

May 


\section{TABLE OF CONTENTS}

SUMMARY 4

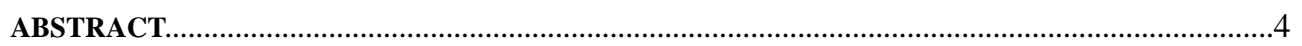

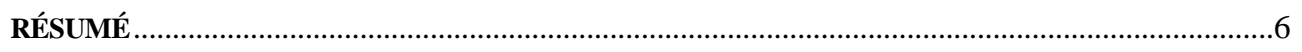

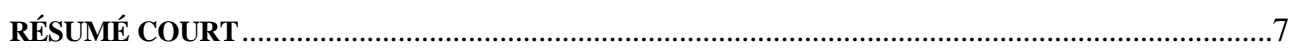

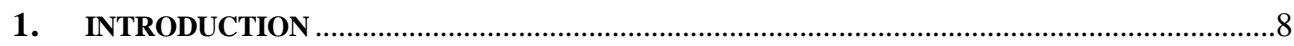

2. HOW TO CLASSIFY? DRAWING LESSONS FROM THE LITERATURE..................................



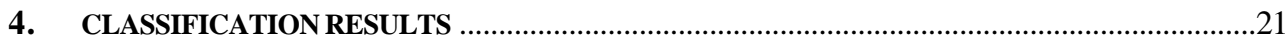

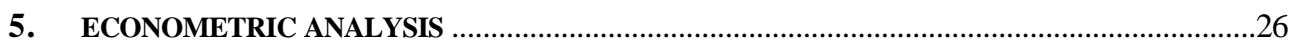

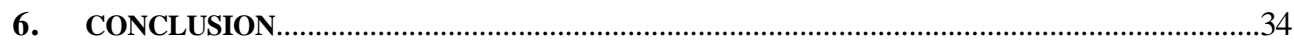

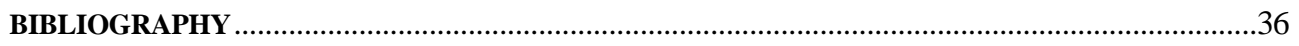

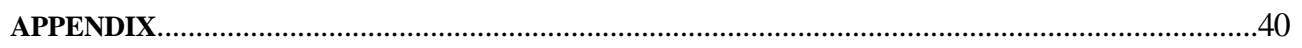

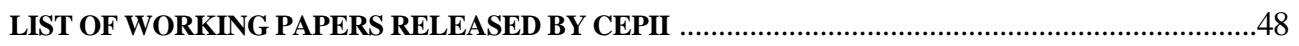




\section{DOES EXCHANGE RATE REGIME EXPLAIN DIFFERENCES IN ECONOMIC RESULTS} FOR ASIAN COUNTRIES ?

\section{SUMMARY}

The paper aims at determining whether exchange rate regimes have an impact on inflation and growth, on a sample of ten major Asian countries for the period 1990:1-2001:4.

First, we review the main existing de facto classifications for exchange rate regimes and find some features that could distort results. For example, in the most famous one, by Levy-Yeyati and Sturzenegger, (2000, 2003), in addition to the number of inconclusive observations, ruptures of anchorage are not identified and mostly classified as floats, which makes the "float" category not really relevant. This caveat is solved in the "natural classification" by Calvo and Reihnart (2003). However, this classification does not take into account the central banks' behaviour on the forex market, which can be important to discriminate between "managed float" and "float".

Secondly, we propose a new statistical method for identifying de facto exchange rate regimes: observations are classified into four categories: float, managed float, crawling peg and peg. We take stock of the results of Bénassy-Quéré and Coeuré (2000), evidencing the dollar as the main anchor currency in the Asian countries. The procedure includes several steps: successively taking into account the trends in the exchange rate levels in order to separate crawling pegs from pegs, comparing the variances in the exchange rates and forex reserves changes to the ones of a benchmark sample of floating currencies. More precisely, we calculate quarterly variances of exchange rates using weekly data and carry out a Fisher test for comparing this variance to the one calculated on a benchmark sample of floating currencies: USD/DEM-EUR, USD/JPY and USD/GBP. We perform the same kind of test for forex reserves to discriminate between float and managed float. In a final stage, devaluation periods are identified, on the basis of quarterly trend of depreciation. This method yields quarterly results that are checked to be consistent with common knowledge: most South Asian countries had de facto pegs before the Asian crisis and let their currency float afterwards.

Thirdly, we use this classification for assessing the effects of exchange rates regimes on inflation and growth. We perform pooled regressions with lagged exchange rate regimes dummies and several control variables. Results show that pegs are associated with weaker growth and lower inflation. However, results on inflation are questionable, as an endogeneity bias is not excluded.

\section{ABSTRACT}

The paper aims at determining whether exchange rate regimes have an impact on inflation and growth for a sample of ten major Asian countries for the period 1990:01-2001:04. First, we try to improve upon existing de facto classifications and propose a new statistical method for identifying de facto exchange rate regimes: observations are classified into four categories: float, managed float, crawling peg and peg. The procedure includes several successive steps: taking into account the trends in the exchange rate levels, comparing the 
Does Exchange Rate Regime Explain Differences in Economic Results for Asian Countries?

variances in the exchange rates and forex reserves changes to a benchmark sample of floating currencies. Devaluation periods are also identified. This method yields quarterly results that are checked to be consistent with common knowledge. Second, we use this classification for assessing the effects of exchange rates regimes on inflation and growth. We perform pooled regressions with lagged exchange rate regimes dummies and several control variables. Results show that pegs are associated with weaker growth than floating exchange rate regimes. Results on inflation are more questionable, as an endogeneity bias is not excluded.

J.E.L. classification:

Keywords:
F33

Exchange rate regime, Economic performance, Asian countries 


\section{LES RÉGIMES DE CHANGE ONT-ILS UNE INFLUENCE SUR LES PERFORMANCES ÉCONOMIQUES DES PAYS ASIATIQUES?}

\section{RÉSUMÉ}

Le but de cette étude est de déterminer si les régimes de change ont un impact sur l'inflation et la croissance sur un échantillon de dix pays asiatiques pour la période 1990:01-2001:04. Premièrement, nous passons en revue les méthodes de classifications existantes et identifions un certain nombre de caractéristiques qui peuvent biaiser les résultats. Par exemple, dans la classification fameuse de Levy-Yeyati and Sturzenegger, (2000, 2003), en plus du nombre important d'observations sur lesquelles la méthode ne peut conclure, les ruptures d'ancrage ne sont pas identifiées. En conséquence, ces observations sont souvent classées à tort dans la catégorie « flottement », ce qui rend cette catégorie peu pertinente. Ce travers ne se retrouve pas dans la classification de Calvo and Reihnart (2003) . Cependant, cette méthode ne prend pas en compte les interventions des banques centrales sur le marché des changes, pourtant décisives pour distinguer entre les flottements gérés et les flottements purs.

Deuxièmement, nous proposons une nouvelle méthode statistique pour identifier les régimes de change de facto : les observations sont classées en quatre catégories: taux de change flottants, flottement géré, taux de change fixes et à parités glissantes. Nous nous appuyons sur les résultats obtenus par Bénassy-Quéré and Coeuré (2000), qui mettent en évidence l'ancrage des monnaies asiatiques sur le dollar. La procédure mise en œuvre comporte plusieurs étapes successives: la prise en en compte des tendances des taux de changes - afin de départager les taux de changes fixes des parités glissantes -; la comparaison des variances des taux de change et des réserves officielles avec celles d'un échantillon de référence composé de monnaies flottantes. Plus précisément, nous calculons des variances trimestrielles des taux de change en utilisant des données hebdomadaires et faisons un test de Fisher pour comparer les variances obtenues pour chaque pays asiatique à celles d'un échantillon de référence composé de monnaies que nous considérons comme flottantes : USD/DEM-EUR, USD/JPY et USD/GBP. Nous procédons au même test en ce qui concerne les réserves officielles pour séparer les flottements des flottements gérés. Dans une étape finale, nous identifions les périodes de dévaluation sur la base de la tendance trimestrielle. La méthode donne des résultats qui permettent de retrouver les faits stylisés, mis en évidence dans les études sur la question : la plupart des pays asiatiques avaient des régimes de change fixes de facto avant la crise de 1997 et ont laissé flotter leur monnaie ensuite.

Troisièmement, nous utilisons cette classification pour évaluer les effets des régimes de change sur l'inflation et la croissance. Pour cela, nous faisons des régressions empilées avec des variables muettes représentant les régimes de change et des variables de contrôle. Les résultats montrent que les taux de change fixes sont associés à une croissance plus faible que les changes flottants. L'effet sur le taux de croissance persiste après correction d'un biais éventuel d'endogénéité. Les résultats sur l'inflation sont moins tranchés car un biais d'éndogénéité n'est pas exclu. 


\section{RÉSUMÉ COURT}

Le but de cette étude est de déterminer si les régimes de change ont un impact sur l'inflation et la croissance sur un échantillon de dix pays asiatiques pour la période 1990:01-2001:04. Premièrement, nous essayons d'améliorer les classifications existantes en proposant une nouvelle méthode statistique pour identifier les régimes de change de facto : les observations sont classées en quatre catégories: taux de change flottants, flottement géré, taux de change fixes et à parités glissantes. La procédure mise en œuvre comporte plusieurs étapes successives: la prise en en compte des tendances des taux de changes, la comparaison des variances des taux de change et des réserves officielles à celles d'un échantillon de référence composé de monnaies flottantes. Deuxièmement, nous utilisons cette classification pour évaluer les effets des régimes de change sur l'inflation et la croissance. Pour cela, nous faisons des régressions empilées avec des variables muettes représentant les régimes de change et des variables de contrôle. Les résultats montrent que les taux de change fixes sont associés à une croissance plus faible que les changes flottants. Les résultats sur l'inflation sont moins tranchés car un biais d'éndogénéité ne peut être exclu.

J.E.L.: F33

Mots-clés: régime de change, performance économique, Asie 


\title{
DOES EXCHANGE RATE REGIME EXPLAIN DIFFERENCES IN ECONOMIC RESULTS
} FOR ASIAN COUNTRIES ? ${ }^{1}$

\author{
Virginie Coudert ${ }^{2}$ and Marc Dubert ${ }^{3}$
}

\section{INTRODUCTION}

The exchange rate regime is one of the central choice of the economic policy. However, the debate over fixed-versus-floating systems has often been muddied by the recommendations of the International Monetary Fund (IMF), which have shifted according to circumstances. In the wake of the 1997 Asian crisis, the IMF accused "soft" pegs, not really of playing a part in the Asian meltdown, but of amplifying the cost of the crisis. It is true that pegged exchange rates encouraged growth in unhedged foreign-currency debt and currency mismatch of balance-sheets. This pushed up the costs of devaluation for borrowers, triggering chains of business and bank failures. These events, together with the massive losses incurred by the monetary authorities as they sought to defend their exchange rates from speculative attack, resulted in an even higher bill for the crisis resolution and, hence, played a role in the ensuing IMF's doctrinal shift. Having long supported fixed exchange rate regimes as a weapon in the fight against inflation, the IMF turned to "corner" solutions, based on hard pegs - currency boards or dollarisation - or pure floats, in the late nineties (Fischer, 2001). However, there was another shift of doctrine, after the Argentine crisis in 2001-2002. Since that time, the IMF has stopped recommending currency boards as a credible solution and has switched to its current doctrine of floating arrangements with inflation targeting (Rogoff and alii, 2003). Such changes in recommendations show the great uncertainty, that still undermines this issue.

Accordingly, the debate must be recast to include research that analyses countries' macroeconomic performances according to their exchange rate regime and get ridded of partisan considerations. In theory, the nominal regime should be able to influence inflation, by creating an external anchor for the currency, and thus have a neutral impact on longterm growth. But if the risks of crisis are increased by keeping rates fixed for too long, macroeconomic performance is likely to be affected.

To briefly sum up this long debate, let us go back to Obsfeld and Rogoff (1995), whose article, "The Mirage of Fixed Exchange Rates", warns against fixed regimes. Their paper argues that such systems last on average for a couple of years and are regularly followed by a collapse in the exchange rate and a currency crisis. In countries with stubborn inflation, a

\footnotetext{
${ }^{1}$ We thank Agnès Bénassy-Quéré and Francisco Serranito for helpful comments on a first draft of this paper. We also thank participants of the internal seminar of the CEPN, University of Paris 13, where a first version of the paper was presented in June 2003, especially Jacques Mazier and Dominique Plihon, for their remarks. We are also grateful to participants of the conference on "Econometrics of Emerging Markets" organised by the Applied Econometric Association in November 2003. The opinions expressed are those of the authors and do not reflect the view of institutions they belong to.

Banque de France, CEPII and University Paris 13, CEPN , CNRS-UMR7115

${ }^{3}$ University Paris 13, CEPN , CNRS-UMR7115
} 
fixed exchange rate often causes the real exchange rate to become overvalued. This turns out to be unsustainable in the medium term, leaving the regime vulnerable to speculative attack. Williamson (2000) therefore recommends making fixed exchange rate regimes more flexible by introducing soft crawling bands pegged to currency baskets. In her famous article, "The Mirage of Floating Exchange Rates", Reinhart (2000) says that floating rates are even more of a delusion than fixed ones, for the simple reason that they do not exist. Looking at a large sample of countries, she demonstrates that no emerging country actually allows its exchange rate to float, because the governments of these countries suffer from what Calvo and Reinhart (2002) dubbed the "fear of floating". This subject has spawned an ample literature. But in the end, few empirical studies have considered the issue of how exchange rate regimes affect countries' economic performances. To our knowledge, the only existing studies to offer a statistical analysis of this question are those commissioned by the IMF: Ghosh and alii (1997) and Levy-Yeyati and Sturzenegger (2001), Rogoff and alii (2003).

In this paper, we have focused on a sample of ten Asian countries - China, South Korea, Hong Kong, India, Indonesia, Malaysia, Pakistan, the Philippines, Singapore and Thailand - over the period 1990-2001. This sample is of particular interest, for several reasons. First, these countries employed a diverse array of exchange rate systems during the period under review. Second, they share common characteristics that facilitate a comparative analysis. Third, the crisis that marked this period allows to test the vulnerability of different regimes to speculative attacks.

An important preliminary stage of this study was to identify the "de facto" exchange rate regimes in each country. The recent literature contains several methods for this, notably those of Calvo and Reinhart (2002), and Levy-Yeyati and Sturzenegger (2000, 2003). However, having conducted a critical examination of these methods, we opted to construct one of our own, explained in detail below. The second stage consisted in performing an econometric analysis of the macroeconomic performances of countries according to their identified exchange rate regime. We concentrate on the results in terms of growth and inflation.

The rest of this paper is organised as follows. Section two describes the methods used in the economic literature to identify the de facto regimes actually in use in different countries. Section three explains and justifies our method. Section four sets out the findings and compares them with those of the other available studies. Section five consists of an econometric analysis of the effects of exchange rate regimes. Section six concludes.

\section{HOW TO CLASSIFY? DRAWING LESSONS FROM THE LITERATURE}

Several studies were carried out in the early 1990s with the aim of identifying "de facto" exchange rate regimes. Two methods were used for this. The first one analyses central bank interventions through changes in official reserves and interest rates; Popper and Lowell (1994) employed this method to examine the situation in the United States, Canada, Australia and Japan. The second method, used by Frankel and Wei (1993), consists of an a posteriori analysis of the results of the exchange rate policy by examining changes in parities. In fact, both methods are necessary to assess exchange rate regimes, and they are generally used jointly in the studies described below. 


\subsection{Fear of floating}

Calvo and Reinhart (2002) show that there are major distortions between "de jure" exchange rate regimes, i.e. the ones reported by countries to the IMF, and the "de facto" regimes resulting from the policy that the countries actually pursue. In particular, the two authors demonstrate that most of the countries that announce a floating regime in fact intervene regularly on the foreign exchange market to contain the parity. According to Calvo and Reinhart(2002), this points to a widespread "fear of floating" among emerging countries, stemming from the inability of floating exchange rates to stabilise their economic shocks. This is due to several factors, which are specific to emerging countries. Especially, the "currency mismatch" in domestic agents' balance sheets - ie the higher share of dollarised liabilities compared to assets - provides an incentive for stabilising the currency, since any depreciation is costly. (see Hausmann et alii, 1999, Coudert, 2004).

Calvo-Reinhart (2002) and Reinhart (2000) cross-reference several criteria to identify the "de facto" exchange rate regimes. They take account of the variance of exchange rates, interest rates and official reserves (Table 1). Floats are characterised by high variance in the exchange rate and low variance in official reserves, while the variance of the interest rate depends on the intermediate targets of monetary policy. Pegged regimes are divided into four categories (Table 1). The first of these is credible pegs, where the nominal exchange rate remains fixed and the interest rate is equal to the interest rate of the anchor currency, with interventions of varying sizes. Non-credible pegs are characterised by large swings in interest rates and reserves. "Disguised" pegs, split into Type 1 and Type 2, display low exchange rate variance, with, as a corollary, high interest rate variance. Reserves vary little in Type 1 regimes, where the parity is managed in the money market, but vary considerably in Type 2 regimes as a result of interventions in the currency market.

For fixed exchange rate regimes, the bilateral exchange rate reported is the rate against the anchor currency. In other cases, the exchange rate against the dollar is used, except for European currencies, where the peg to the mark is tested.

Table 1: Characterisation of exchange rate arrangements, Reinhart 2000

\begin{tabular}{|c|c|c|c|}
\hline Exchange rate regime & $\begin{array}{l}\text { Variance of the } \\
\text { nominal exchange rate }\end{array}$ & $\begin{array}{c}\text { Variance of the } \\
\text { nominal interest } \\
\text { rate }\end{array}$ & $\begin{array}{c}\text { Variance of } \\
\text { forex } \\
\text { reserves }\end{array}$ \\
\hline Float / money-supply rule & High & $?$ & 0 \\
\hline Float / interest rate smoothing & High & Low & 0 \\
\hline Credible peg & 0 & $=$ variance of $\mathrm{i}^{*}$ & $?$ \\
\hline Non-credible peg & 0 & High & High \\
\hline $\begin{array}{l}\text { Non-credible peg in disguise, } \\
\text { Type } 1\end{array}$ & Low & High & Low \\
\hline $\begin{array}{l}\text { Non-credible peg in disguise, } \\
\text { Type } 2\end{array}$ & Low & High & High \\
\hline
\end{tabular}

Source: Reinhart, 2000.

Once the regime has been characterised according to Table 1, it is necessary to establish what constitutes "high" and "low" variance. Calvo and Reinhart solve the problem by 
considering the major currencies, such as the USD/JPY and the USD/DEM, to be floating. By definition, they assume that these currencies exhibit high variance in terms of the exchange rate and low variance in terms of reserves. As a result, the authors use these currencies as a benchmark against which to assess the behaviour of others.

Calvo and Reinhart calculate the empirical probability that the monthly percentage change in the exchange rate will fall within a band of $\pm 1 \%$ and $\pm 2.5 \%$. The same calculation is done for official reserves and interest rates. The sample includes a large number of countries over the period 1973-1999. The results show, for example, that the probability of the percentage change in the exchange rate to fall within a band of $\pm 1 \%$ is only $27 \%$ for the USD/DEM and is much higher for the emerging countries. For example, this figure amounts to $73 \%$ for Bolivia. Therefore, the currencies of emerging economies appear to be comparatively far more stable than the major floating currencies. Emerging countries' reserves and interest rates are also more variable, revealing a stronger de facto exchange rate fixity.

This analysis is useful, both in its results and in its method. However, we identify three main drawbacks. First, there is no statistical test to differentiate variances between the emerging country being examined and a country with a floating exchange rate. Second, crawling pegs, which were frequently used during the period, are not identified. Third, interest rates do not seem to play a genuinely discriminating role, because their variance may be high regardless of whether the regime is fixed or floating.

Consequently, we do not use Calvo and Reinhart's (2002) calculation method. We are not including interest rates among the criteria to be taken into account. We have, however, drawn on their research by comparing emerging economies against a benchmark sample of floating currencies.

\subsection{The Levy-Yeyati and Sturzenegger classification method}

Levy-Yeyati and Sturzenegger (LYS) $(2000,2003)$ also propose an exhaustive statistical analysis of the exchange rate regimes used around the world. Their "LYS" classification is based on the volatility of the exchange rate and of the official reserves. To discriminate between crawling pegs and dirty floats, two measures are made for the volatility of the exchange rate: the average of the absolute monthly percentage change in the exchange rate, and the standard deviation of the monthly percentage change in the exchange rate, both being calculated for a calendar year. Reserves volatility is measured by the average of absolute monthly change in net dollar reserves divided by the monetary base of the previous month taken in dollars too. The sample involves 153 countries in the period 19742000.

Straightaway this approach makes two improvements on the previous study by Calvo and Reinhart. First, the interest rate is not one of the criteria. Second, crawling pegs are identified by average fluctuations in exchange rate levels and low variance of their percentage changes. Table 2 describes the different exchange rate regimes identified in this analysis. The problem of the anchor was dealt with as follows: for countries reporting a peg to a given currency, the exchange rate used was calculated against that currency; otherwise, the exchange rate was calculated against a number of currencies (USD, FRF, 
DEM, GBP, SDR, XEU, JPY) and the bilateral exchange rate exhibiting the lowest variance was used. Countries that pegged their currency to a basket were excluded unless the central peg parity or the basket weights were known.

Table 2: Characterisation of exchange rate regimes by LYS (2000, 2003) (*)

\begin{tabular}{lccc}
\hline $\begin{array}{c}\text { Exchange } \\
\text { rate regime }\end{array}$ & $\begin{array}{c}\text { Fluctuations in the } \\
\text { exchange rate level } \\
\text { Average }|\Delta \mathbf{e} / \mathbf{e}|\end{array}$ & $\begin{array}{c}\text { Fluctuations in the } \\
\text { percentage change of the } \\
\text { exchange rate } \\
\text { Variance }(\Delta \mathbf{e} / \mathbf{e})\end{array}$ & $\begin{array}{c}\text { Fluctuations in the } \\
\text { reserves ratio } \\
\text { Average } \mid \Delta \mathbf{R} / \mathbf{B}\end{array}$ \\
\hline Flexible & High & High & Low \\
Dirty Float & Average & Average & Average \\
Crawling peg & Average & Low & Average/High \\
Peg & Low & Low & High \\
Inconclusive & Low & Low & Low \\
\hline
\end{tabular}

(*) e: nominal exchange rate against anchor currency, R: net reserves in dollars, B: monetary of the previous month in dollars

Source: Levy-Yeyati and Sturzenegger (2000, 2003)

Next, the problem is once again to determine whether the values of the calculated variables are low or high. Levy-Yeyati and Sturzenegger solve it by means of cluster analysis. Once the three variables have been computed for each year and for each of the countries being analysed, the entire set of observations is grouped into five clusters: flexible, dirty float, crawling peg, fixed and inconclusive, according to the criteria given in Table 2. The cluster analysis is made in two rounds: among 2860 observations, 1062 are classified in the first round, the remaining 1798 observations are submitted to the same treatment, in order to reduce the number of inconclusive observations. At the end of the second round, 698 observations, which amount to $24 \%$ of the total, are still found "inconclusive".

This is a serious drawback of the cluster analysis. Strangely, this "inconclusiveness" is found for observations that seem very easy to classify statistically, because their exchange rates are almost entirely fixed. That is the case of currency boards. For example, Argentina, which had a currency board in place from 1991 to 2001, and a 1-for-1 exchange rate against the dollar in the whole period, is deemed to have an "inconclusive" regime in 1996-19971998. It is the same for currency boards in Lithuania from 1995 to 2000 and Estonia from 1994 to 1997 . To solve this problem, the authors had to add another step to the process, in the latest version of their study. They considered that the inconclusive observations are pegs either if the volatility in their exchange rate is zero, or if they are declared as fixers by the IMF and the volatility in their nominal exchange rate is smaller than $0,1 \%$.

Obviously, Argentina's currency board fulfils this second condition. This latest step allows to drastically reduce the number of inconclusive observations, which falls to $2.4 \%$.

The LYS method is interesting because it takes a statistical approach to classification, unlike the previous method, which includes a subjective judgement when assessing the differences between countries. Many studies have used the LYS classification as a basis, for it is available on-line on their web site. For example, Von Hagen and Zhou (2002) used 
this classification to assess de facto arrangements in the transition economies; Juhn and Mauro (2002) used it when estimating the determinants of exchange rate regimes with a Probit model.

However, the LYS classification is not entirely satisfying. First, it is not reliable for the years of changes in regimes or when a devaluation occurs. This is linked to the fact that regimes are assessed on a calendar year basis. For example, in a year of devaluation, a peg could be wrongly classified as a dirty float or a crawling peg. This is the case for France in $1981,82,83,86$, classified as "dirty float", although the exchange rate was pegged inside the European Monetary System, with devaluations within these years. Second, the classifications of many observations are questionable: for example, France was classified as a "dirty floater" in 1987, 1995, 1996, and found "inconclusive" in 1997, although the exchange rate was pegged within the European Monetary System without devaluation in those periods; Poland was deemed as a floater in the whole nineties, although his exchange rate followed a crawling peg with bands from 1993 to 1999; India was considered as a floater or "inconclusive" in the nineties, although the exchange rate regime was mainly a crawling peg, with frequent devaluations (see figure 1 in appendix).

\subsection{Further approaches to classification}

Bénassy-Quéré and Coeuré $(2000,2003)$ propose a method aimed at improving anchor determination. In particular, they seek to take better account of de facto pegs to currency baskets, which are overlooked in other classifications, especially when they are not revealed by the monetary authorities. One major caveat when trying to find the anchor currency is that the choice of the numeraire can distort results. The advantage of the method by Bénassy-Quéré and Coeuré $(2000,2003)$ is to get rid of this problem of the numeraire choice. This is done by giving a symmetrical role to all key currencies in GMM estimations. The authors' results confirm the numerous unannounced pegs to the dollar: a large number of the currencies among the 111 in the sample are estimated to be pegged to the dollar, while only few of them declared a peg to the IMF. The importance of the dollar anchor in Asian countries is also evidenced, confirming the former results obtained by Bénassy-Quéré (1996). Here, we take stock of these results, postulating that the Asian currencies are pegged to the dollar, when pegged.

Poirson (2001) introduces a continuous indicator to measure the degree of flexibility of exchange rate regimes. The indicator is the ratio of exchange rate volatility to reserves volatility. Both volatility are calculated as the average of absolute value of monthly percentage changes. As in Levy-Yeyati (2000, 2003), the monthly changes in reserves are normalised by the monetary base. The anchor currency is the dollar, unless the exchange rate against some other currency, such as the JPY, FRF, DEM, GBP or SDR, is less volatile. The indicator has a value of 0 in the case of a completely fixed exchange rate; it tends towards infinity in the case of a totally floating rate with no interventions. Results are calculated for 161 countries for the 12 months of year 1998, with values ranging from 0.000 for the Argentine peso to 5.6 for the yen.

In their so called "natural classification", Reinhart and Rogoff (2002) improve upon existing methods, by using exchange rates on parallel markets for countries with a dual currency market. Their classification is carried out by successive sorting. First, they check if there is a parallel market in the country. If there is one, they proceed to a statistical 
classification (based on the percentage change of the nominal exchange rate in absolute value and on the probability of remaining in a band of fluctuation). If there is a single forex market, they test if the announced regime matches the statistical de facto classification. Their classification is composed of 7 possible regimes: "peg", "band", "crawling peg", "crawling band", "moving band", "managed float" and " "freely floating"”. The classification takes also account of high inflation countries: if the annual inflation rate is higher than $40 \%$ in a country, this observation is classified as "free falling". If the monthly rate of inflation is higher than 50\%, the observation is classified as "hyper float". They use a monthly periodicity, which allows to address the problem of changes in exchange rate arrangements inside the year.

This method is relevant to deal with the issues related on the existence of a parallel forex market and on hyperinflation. However, it is not necessary in our sample, as these problems do not occur for the considered Asian countries (except for some observations on China, from 1990 to 1994). Moreover, a drawback of this classification is to be based only on the behaviour of exchange rate and to neglect the changes in reserves, which can reveal the interventions of the central bank.

\section{THE CLASSIFICATION METHOD USED IN THIS STUDY}

\subsection{Aims and principles of the classification}

Our classification is based on the generally accepted principles for characterising exchange rate regimes. Floating systems feature a highly volatile nominal exchange rate and low level of intervention by monetary authorities. Conversely, pegged regimes display low volatility in the nominal exchange rate but large swings in reserves resulting from interventions by the central bank to identify two intermediate types of arrangement: the managed (or "dirty") float, typified by large nominal fluctuations and interventions by the monetary authorities, and the crawling peg, identified by an annual trend of depreciation in the nominal exchange rate and a stable "detrended" parity.

In sum, we separate exchange rate regimes into the following categories (see Table 3):

pure float: high variance in the exchange rate, low volatility in official reserves;

managed float: high variance in the exchange rate, high volatility in official reserves;

crawling peg: strictly positive trend in the annual exchange rate ; (above a given threshold $\mathrm{x} 1$, in order to exclude very small trends that are not relevant); low volatility in the detrended exchange rate;

peg: no trend in the annual exchange rate (or trend under a given threshold $\mathrm{x} 1$ ), low volatility in the nominal exchange rate without trend.

We also add an important category that is missing in previous studies: devaluations. It is crucial to detect these episodes, during which fixed exchange rates are disrupted. Failure to do so means that pegged regimes that devalue are likely to be grouped with floaters. 
Table 3: Characteristics of exchange rate regimes, this study

\begin{tabular}{lccc}
\hline Type of regime & $\begin{array}{c}\text { Trend in nominal } \\
\text { exchange rate (1) }\end{array}$ & $\begin{array}{c}\text { Quarterly variance in } \\
\text { nominal exchange rate (1) } \\
\text { (detrended if trend }>\mathbf{0})\end{array}$ & $\begin{array}{c}\text { Variance of } \\
\text { reserve changes }\end{array}$ \\
\hline \multicolumn{1}{c}{$\underline{\text { Float }}$} & - & High & Low \\
Managed float & - & High & High \\
Peg & $\mid$ annual trend $\mid<x 1$ & Low & - \\
Crawling peg & annual trend $>x 1>0$ & Low & - \\
Devaluation & quarterly trend $>x 2$ & - & - \\
\hline
\end{tabular}

(1) The exchange rate is the number of national currency units per dollar, taken in logarithm; trends are calculated from weekly series, $\mathrm{x} 1, \mathrm{x} 2$ are given positive thresholds; in our sample, $\mathrm{x} 1=2 \%$ and $\times 2=6 \%$.

The method used to discriminate between these different regimes is based on a succession of tests (Figure 1). It can be compared to the technique used by Lambert and alii (2002) in their empirical study of Latin American countries. In order to get round the problem of what anchor to use, we assume the dollar to be the anchor currency in the sample, which comprises ten south-east Asian countries. This assumption is supported by studies on anchor currencies by Bénassy-Quéré (1996) and Bénassy-Quéré and Coeuré (2000).

We solve the problem of determining what constitutes high and low variance by considering there is a group of floating currencies - USD/DEM, USD/JPY and USD/GBP which by definition have high exchange rate volatility and low reserve volatility. In this, we are drawing on an idea formulated by Calvo and Reinhart (2002). However, we improve on their method by conducting formal statistical tests on the variances relatively to this benchmark sample of floating currencies. We address the issue of unreliability of annual classifications by drawing up a quarterly classification.

\subsection{Sample and data}

The study spans the 1990:1-2001:4 period and covers ten Asian countries: China, South Korea, Hong Kong, India, Indonesia, Malaysia, Pakistan, the Philippines, Singapore and Thailand. The benchmark sample of floating currencies is made up of three countries: Germany (whose currency is the deutsche mark up to 1998 and the euro after 1999), Japan and the UK. As the classification is made on quarterly basis, an "observation" designates a given quarter for a given country.

In order to construct quarterly variances, we use weekly exchange rates against dollar, extracted from the Datastream base and monthly data on official reserves from the IMF's International Financial Statistics (see appendix 1).

All exchange rate series are taken as logarithm. The exchange rate is defined by the number of national currency units against the dollar, thus a positive change indicates a depreciating currency. 


\subsection{The classification process}

Stage one: sorting observations by the annual trend in the exchange rate

The first stage consists in calculating annual trends from all the weekly exchange rate on a calendar-year basis. This stage is aimed at detecting crawling pegs. As crawling pegs are designed to pre-announce authorised devaluation rates, we separate the period of positive trends, which correspond to a depreciating currency, from the period of negative trends. As implementations of crawling pegs are usually made at the beginning of a calendar year, we compute trend on a calendar year basis.

If the trend is positive, we compute detrended series to distinguish between fixed regimes (pegs and crawling pegs) and floating regimes (pure or managed). Subsequently, the exchange rate series that we use are detrended over periods where the trend is positive. We then go on to step two.

If the trend is negative, we have to establish whether it is "significant" or not.

A trend that is statistically significantly different from zero is not a sufficient criterion: if the trend is very small, we could not rule out the possibility that this might be a pegged exchange rate oscillating weakly within fluctuation bands. For example when trying to implement this method for Argentina during the period of currency board, we found a significant trend for some years, although the rate of change was so small, that the exchange rate was clearly pegged. This kind of problem was also encountered by Levy-Yeyati and Sturzenegger (2000, 2003), who were not able to classify Argentina without setting an arbitrary threshold (in their case, the threshold was set on volatilities).

So we assume a given threshold that we arbitrarily set at $\mathrm{x} 1=2 \%$ annually. This is similar to the level adopted by Bubula and Ötker-Robe (2002). This threshold fits the allowed change in the exchange rate of a pegged currency with fluctuation margins of $\pm 1 \%$. This is the size of fluctuation band retained by the IMF for his definition of a pegged exchange rate.

If the negative trend has an absolute value smaller than $\mathrm{x} 1$, we go on to stage 2 to determine whether we are dealing with a fixed exchange rate regime or a float without trend.

If the negative trend has an absolute value greater than $\mathrm{x} 1$, the regime cannot be a peg or a crawling peg. We therefore immediately deem the country to operate a pure or a managed float, and go directly to stage four.

Stage two: Separating peg and crawling peg from float and managed float by comparing quarterly variances in the exchange rate with those of the benchmark sample.

We calculate quarterly variances in the exchange rate by using weekly data (detrended if the trend is found positive in stage one)). We compare the variances obtained for the Asian 
economies to the average of the variances obtained for major benchmark floating currencies.

Let us designate by $\bar{S}_{1}^{2}$ this empirical quarterly variance of the exchange rate for the Asian country and by $\bar{S}_{0}^{2}$ the empirical quarterly variance of the reference sample. We assume that exchange rates follow a normal distribution, with a theoretical variance $\sigma_{1}{ }^{2}$ for the Asian country and $\sigma_{0}^{2}$ for the benchmark sample. Therefore, the empirical variances, $\bar{S}_{1}^{2}$, calculated with $\mathrm{n}_{1}$ observations, ( $\mathrm{n}_{1}=13$ weekly observations in a quarter), follows a chi-square distribution with $\left(n_{1}-1=12\right)$ degrees of freedom. Since $\bar{S}_{0}^{2}$ is the mean of the empirical variances of the three benchmark floating exchange rates, it is calculated on the basis of $n_{0}=13 \times 3$ data ; it follows a chi-square with $n_{0}-1=38$ degrees of freedom. Therefore, the ratio of the two empirical variances divided by their theoretical values follows a Fisher distribution:

$$
\frac{{\overline{S_{0}}}^{2} / \sigma_{0}{ }^{2}}{\bar{S}_{1}^{2} / \sigma_{1}^{2}} \rightarrow F\left(n_{0}-1, n_{1}-1\right)
$$

The null hypothesis $\mathrm{H}_{0}$ is that in a given quarter, the variance of the exchange rate in the Asian country is smaller than the one of the benchmark sample of floating exchange rates:

$$
\mathrm{H}_{0}: \frac{\sigma_{0}^{2}}{\sigma_{1}^{2}}>1 \Leftrightarrow \sigma_{1}^{2}<\sigma_{0}^{2}
$$

We carry out this variance equality test at a significance level of $\alpha=5 \%$. We accept the null hypothesis if the ratio of the empirical variances is such that :

$$
\frac{{\overline{S_{0}}}^{2}}{{\overline{S_{1}}}^{2}}>f_{\alpha}
$$

where $f_{\alpha}$ is the $(1-\alpha)$ quantile of the repartition function of $\mathrm{F}\left(\mathrm{n}_{0}-1, \mathrm{n}_{1}-1\right)$. This is equivalent to the condition:

$$
\bar{S}_{1}^{2}<\frac{1}{f_{\alpha}}{\overline{S_{0}}}^{2}
$$

This amounts to consider that the exchange rate variance is "low" if it is smaller than $41 \%$ of the variance of the benchmark floating currencies. If it is greater, we reject the null hypothesis and consider the country as having a "high" variance of his exchange rate during the quarter.

On the basis of this test, we are able to draw up a first sorting. In a given quarter, a country is classified as a peg or a crawling peg if the null hypothesis is accepted, which means that his exchange rate variance is smaller than $41 \%$ of the one of the benchmark sample. Otherwise, the country is deemed to have adopted a float or a managed float. 


\section{Stage three: Separation of pegs from crawling pegs on the basis of their annual trend}

Any country qualified as pegged or crawling peg under stage two is classified as having a peg if the annual trend of its exchange rate (determined in stage one) is lower than $\mathrm{x} 1=2 \%$, and a crawling peg otherwise.

\section{Stage four: Separating pure from managed floats by comparing quarterly variances in the percentage rate of reserves with the benchmark countries}

For the observations classified as pure floats or managed floats in former stages, we calculate the variance of the percentage change of official reserves, in order to discriminate pure from managed floats. We are not able to use a quarterly variance, because our reserves series are monthly. To get round this problem, for a given quarter, we calculate the variance of reserves on a 5-quarter period, centred around the observation. Therefore, it is computed on 15 months: the six previous months, the quarter in question, and the six following months.

The advantage of this approach is that it takes account of the following frequent situations : a country has adopted a managed float and is ready to intervene in case of large movements of the exchange rate, howeverit does not intervene in a given quarter, because market conditions do not require such action. In considering the variance calculated only in the given quarter, the country could be wrongly classified as a pure float.

We carry out a variance equality test between these quarterly variances of changes in reserves for the Asian countries and the major floating currencies. Assuming that the monthly rates of change in reserves follow a normal distribution, the quarterly variances in these rates, calculated on a 15 -month basis, follow a chi square distribution with $n_{1}{ }_{1}=14$ degrees of freedom, the average variance of the benchmark sample follow a chi square distribution with $n_{0}=44$ degrees of freedom. Thus, we can make the same kind of Fisher test as described previously.

Now, the null hypothesis $\mathrm{H}_{0}{ }_{0}$ is that in a given quarter, the variance of the reserves change $\sigma^{\prime}{ }^{2}$ in the Asian country is greater than the one of the benchmark sample of floating exchange rates $\sigma_{0}{ }_{0}^{2}$ :

$\mathrm{H}_{0}: \sigma^{{ }^{2}}{ }^{2}>\sigma^{\prime}{ }_{0}^{2}$

The ratio of empirical variances of the two samples, noted respectively, $\bar{S}_{0}^{\prime}{ }^{2}, \bar{S}_{1}^{\prime}{ }_{1}^{2}$ is such that:

$$
\frac{\bar{S}_{1}{ }_{1}^{2} / \sigma^{\prime}{ }_{1}^{2}}{\overline{S^{\prime}{ }_{0} 2 / \sigma_{0}{ }^{2}}} \rightarrow F\left(n_{1}^{\prime}-1, n_{0}^{\prime}-1\right)
$$

As previously, we carry out this variance equality test at a significance level of $\alpha=5 \%$. We accept the null hypothesis if the ratio of the empirical variances is such that :

$$
\frac{\bar{S}_{1}^{\prime} 2}{\bar{S}_{0}^{\prime}{ }^{2}}>f^{\prime} \alpha
$$


where $f^{\prime} \alpha$ is the (1- $\left.\alpha\right)$ quantile of the repartition function of $F\left(n^{\prime}{ }^{-1}, n^{\prime} 0^{-1}\right)$. This is equivalent to the condition:

$$
\bar{S}_{1}^{\prime}{ }^{2}>f_{\alpha}^{\prime} \bar{S}_{0}^{\prime 2}
$$

This amounts to considering that the regime is a managed float if the reserves changes have a variance, which is greater than 2 times the variance of the benchmark sample. If not, the observation is classified as a pure float.

\section{Stage five: detecting devaluation}

In a final and independent stage, we calculate quarterly deterministic trends for each observation in order to identify periods in which a devaluation has occurred. If the quarterly trend is greater than a given threshold $\mathrm{x} 2$, we classify the observation as a devaluation. Therefore, this category includes ruptures of pegs and crawling pegs, but also sharp depreciation periods in floating and managed floats regimes.

Given our sample of Asian countries, where inflation is low and nominal depreciations are moderate except during crises, we set the threshold at 6\%. Obviously, this threshold, somewhat arbitrary, depends on the sample. It seems to fit to what we know of devaluation size in the area. If we had been dealing with Latin America, for example, we would have set a higher level. For European Union countries, for example in the former Exchange Rate Mechanism, this would have been smaller, as devaluation of 2 or $3 \%$ occurred. 
Figure 1: The classifying procedure

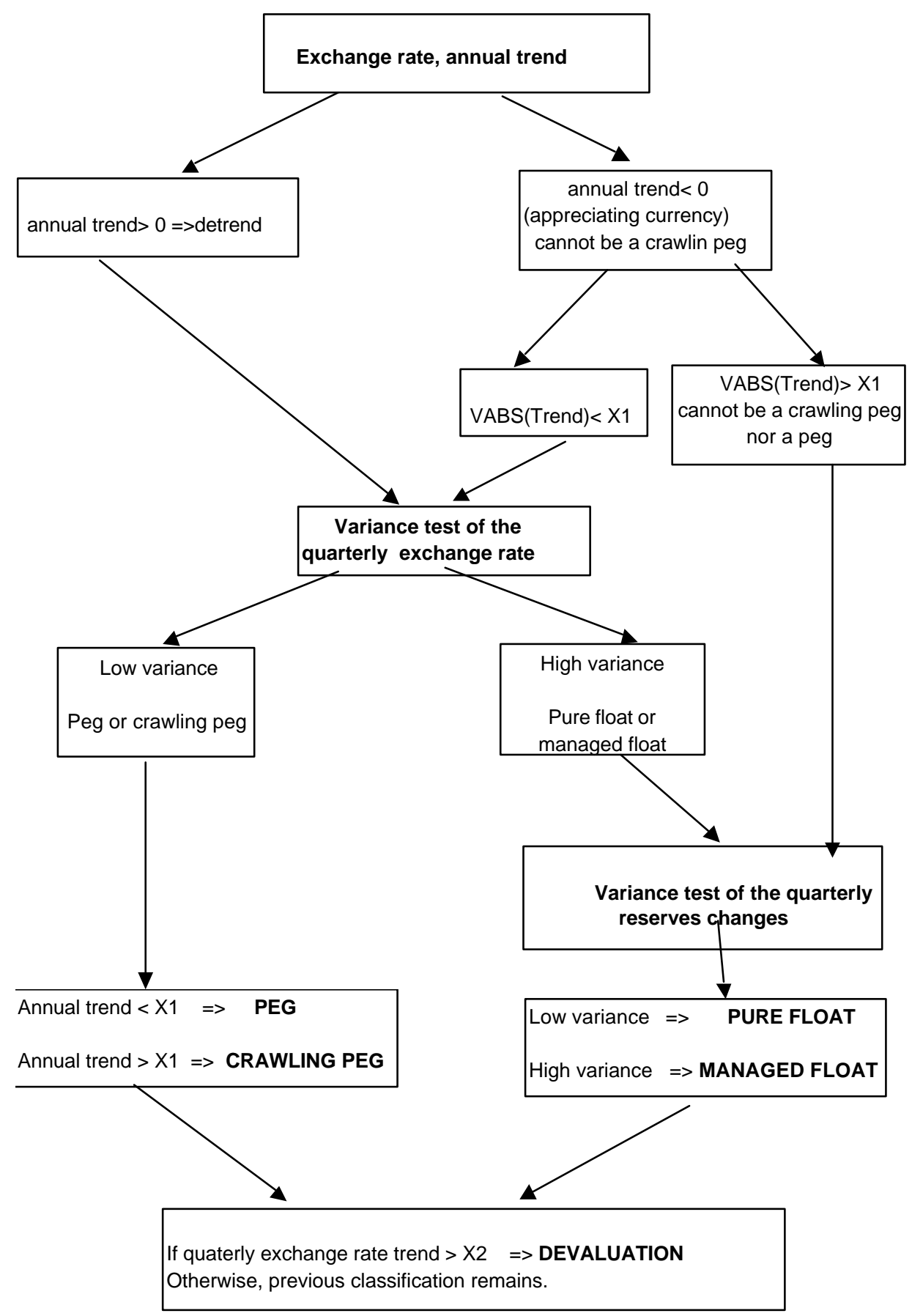




\section{CLASSIFICATION RESULTS}

We used this method of successive tests to draw up a quarterly classification for exchange rate regimes adopted by the ten Asian countries under examination over the 1990-2001 period. To facilitate comparison between the existing classifications, and to present the results in a more condensed form, we draw an annual classification from the quarterly figures (table 4). The annual exchange rate regime presented in this table is the one found in the majority of the four quarters. If two regimes share equal prominence, both are indicated. This annual classification is only provided for giving a synthetic view of the results in this section. It is not used in the calculations performed in section 5. Complete quarterly results are given in appendix 2 .

\section{1 de facto exchange rate policies of the Asian countries}

This "de facto" classification highlights some stylised facts about the exchange rate policy in the area. It exhibits the strong links of the Asian currencies to the dollar until the 1997 crisis and the softening of this constraint afterwards.

Table 4: De facto exchange rate regimes identified by our classification method

\begin{tabular}{|c|c|c|c|c|c|c|c|c|c|}
\hline & \multicolumn{2}{|l|}{ Thailand } & \multicolumn{2}{|l|}{ Malaysia } & \multicolumn{2}{|l|}{ India } & \multicolumn{2}{|c|}{ Indonesia } & $\begin{array}{l}\text { Hong } \\
\text { Kong }\end{array}$ \\
\hline 1990 & \multicolumn{2}{|l|}{ Float } & \multicolumn{2}{|l|}{$\mathrm{Peg}$} & \multicolumn{2}{|l|}{ Crawl } & \multicolumn{2}{|l|}{ n.a } & Peg \\
\hline 1991 & \multicolumn{2}{|l|}{ Peg } & \multicolumn{2}{|l|}{ Peg } & \multicolumn{2}{|c|}{ Managed/Devaluation } & \multicolumn{2}{|l|}{ n.a } & Peg \\
\hline 1992 & \multicolumn{2}{|l|}{ Peg } & \multicolumn{2}{|l|}{ Float } & \multicolumn{2}{|c|}{ Craw 1/Devaluation } & \multicolumn{2}{|l|}{ Crawl } & Peg \\
\hline 1993 & \multicolumn{2}{|l|}{ Peg } & \multicolumn{2}{|l|}{ Peg } & \multicolumn{2}{|c|}{ Crawl/Devaluation } & \multicolumn{2}{|l|}{ Crawl } & Peg \\
\hline 1994 & \multicolumn{2}{|l|}{ Peg } & \multicolumn{2}{|l|}{ Managed } & \multicolumn{2}{|c|}{ Peg } & \multicolumn{2}{|l|}{ Crawl } & Peg \\
\hline 1995 & \multicolumn{2}{|l|}{ Peg } & \multicolumn{2}{|l|}{ Peg } & \multicolumn{2}{|c|}{ Crawl/Devaluation } & \multicolumn{2}{|l|}{ Crawl } & Peg \\
\hline 1996 & \multicolumn{2}{|l|}{ Peg } & \multicolumn{2}{|l|}{ Peg } & \multicolumn{2}{|l|}{ Peg/Float } & Peg & & Peg \\
\hline 1997 & Managed/D & evaluation & Managed/l & evaluation & Crawl/Dev & luation & Float/D & evaluation & Peg \\
\hline 1998 & Float/Deval & uation & Float/Deva & lation & Crawl/Dev & luation & Float/D & evaluation & Peg \\
\hline 1999 & Crawl/Deva & luation & Peg & & Crawl & & Float/D & evaluation & Peg \\
\hline 2000 & Crawl & & Peg & & Crawl & & Float/D & evaluation & Peg \\
\hline 2001 & Crawl/Float & & Peg & & Crawl & & Float/D & evaluation & Peg \\
\hline & China & Phili & pines & Sout & Korea & Singa & & Pal & $\tan$ \\
\hline 1990 & n.a & n.a & & Crawl & & Float & & Crawl & \\
\hline 1991 & n.a & n.a & & Crawl & & Float & & Crawl & \\
\hline 1992 & Devaluation & Float/Deva & lation & Crawl & & Peg & & Crawl & \\
\hline 1993 & $\begin{array}{l}\text { Crawl/ } \\
\text { Devaluation }\end{array}$ & Crawl/Floa & & Crawl & & Float & & Managed & evaluation \\
\hline 1994 & $\begin{array}{l}\text { Managed/ } \\
\text { Float }\end{array}$ & Managed/F & oat & Float & & Float & & Peg & \\
\hline 1995 & Peg & Crawl/Dev & luation & Peg & & Peg & & Crawl/De & luation \\
\hline 1996 & Peg & Peg & & Crawl/Flo & & Peg & & Managed/ & evaluation \\
\hline 1997 & Peg & Managed/I & evaluation & Managed/ & evaluation & Crawl/Der & luation & Crawl/De & luation \\
\hline 1998 & Peg & Devaluatio & & Managed/ & evaluation & Peg/Deval & tion & Managed/ & evaluation \\
\hline 1999 & Peg & Crawl/Dev & luation & Peg & & Peg & & Crawl & \\
\hline 2000 & Peg & Crawl/Floa & & Crawl/De & luation & Crawl & & Crawl/De & luation \\
\hline 2001 & Peg & Float & & Float & & Crawl & & Crawl/Mr & iged \\
\hline
\end{tabular}


Between 1990 and 1995, six countries (Thailand, Indonesia, India, Korea, Hong Kong, Pakistan), among the ten in the sample, chose exchange rate regimes directly anchored to the dollar (peg or crawling peg). The four other countries adopted a more flexible regime, without letting their currency freely float, except Singapore between 1993 and 1994. Broadly, this period is characterised by large interventions of the monetary authorities in order to stabilise their currency. As suggested by the strong growth of reserves accumulated over the period, the interventions mainly consisted in limiting the appreciation of the currencies relatively to the dollar, with the aim of maintaining competitiveness.

During this period, there was a general tendency to harden the peg: Thailand adopted a peg from the beginning of 1990, followed by China in 1994; other countries, like Singapore, hitherto in managed float, reduced their band of fluctuation de facto with respect to the dollar. In 1996, 8 countries out of the ten (Thailand, Malaysia, the Philippines, China, Indonesia, India, Singapore, Hong Kong) followed a strict peg anchored on the dollar. Only Pakistan and Korea preserved some flexibility of their exchange rate versus dollar. However, maintaining the peg was getting more and more difficult, in the countries, like Thailand, where financial liberalisation was implementing and international flows of capital were growing huge.

The outburst of the speculation at the time of the 1997-1998 crisis was lethal for the fixed regimes without capital controls (Thailand, Philippines, Indonesia, Malaysia), leading the monetary authorities to devaluate massively. China was able to maintain the peg because of rigorous exchange rate controls, and also because of a former devaluation in 1994 . Hong-Kong was protected by large amounts of forex reserves and his particular political statute. India and Pakistan kept out the crisis, because of their geographical remoteness and also because they were protected by strict foreign exchange controls; they were able to continue their intermediate regimes, alternating periods of crawling pegs, devaluation, and managed float.

In the aftermath of the crisis, the concerned countries shifted to more flexible regimes: pure float for Korea, Indonesia and Singapore, managed float for Thailand and the Philippines. This result is in line the findings by Hernandez and Montiel (2001). Malaysia was able to come back to a pegged exchange rate, because of her decision to implement strict exchange rate controls, in spite of the disapproval of the IMF.

\subsection{Comparison with other classifications}

Table 5 shows how the countries in our sample are classified by LYS method. The LYS classification has the advantage of spanning a longer period (1973-2000) and covering a much larger number of countries (172). However, it involves several drawbacks.

First, the crisis periods (between 1996 and 1998 depending on the country) are classified as floats, whereas most of the countries suffered major devaluations. Second, LYS results makes no distinction between crawling pegs and managed floats, a problem that applies to a large number of years and countries (22\% of years are classified as Dirty float/Crawling peg in the sample). Third, "inconclusive" observations account for $6 \%$ of the total, notably India in 1992 and 1999, Indonesia in 1994 and Pakistan in 1993; China is not covered. Fourth, some results seem more accurate in our classification: for example, LYS see a dirty float or a crawling peg in Thailand in the early nineties, our detected peg in year 1991-1993 
and 1995-96 seems a better assessment of the exchange rate policy adopted at that time. LYS classify India as having a floating or inconclusive exchange rate regime in the nineties, while we see mostly crawling pegs with devaluations, more in line with the evidence shown by graph 1 .

By using quarterly observations, we are able to detect intra-year changes in the exchange rate regime, which is not done by the LYS method. Furthermore, we discriminate between crawling pegs and managed floats; and identify devaluation. We also are able to classify regimes that fall into the "inconclusive" category under the LYS approach.

Table 5: De facto exchange rate regimes identified by the LYS classification method

\begin{tabular}{|c|c|c|c|c|c|}
\hline & Thailand & Malaysia & India & Indonesia & Hong Kong \\
\hline 1990 & Dirty/CP & Fixed & Dirty/CP & Fixed & Fixed \\
\hline 1991 & Dirty/CP & Dirty/CP & Float & Fixed & Fixed \\
\hline 1992 & Dirty/CP & Dirty & Inconclusive & Fixed & Fixed \\
\hline 1993 & Dirty/CP & Dirty & Float & Fixed & Fixed \\
\hline 1994 & Dirty/CP & Fixed & Inconclusive & Inconclusive & Fixed \\
\hline 1995 & Dirty/CP & Float & Float & Dirty/CP & Fixed \\
\hline 1996 & Inconclusive & Dirty/CP & Float & Dirty/CP & Fixed \\
\hline 1997 & Dirty/CP & Float & Float & Dirty/CP & Fixed \\
\hline 1998 & Dirty/CP & Dirty/CP & Float & Dirty & Fixed \\
\hline 1999 & Float & Fixed & Inconclusive & Dirty/CP & Fixed \\
\hline 2000 & Float & Fixed & Dirty/CP & Dirty/CP & Fixed \\
\hline \multirow[t]{2}{*}{2001} & n.a & n.a & n.a & n.a & Fixed \\
\hline & China & Philippines & South Korea & Singapore & Pakistan \\
\hline 1990 & n.a & Float & Dirty & Dirty & Dirty/CP \\
\hline 1991 & n.a & Dirty/CP & Fixed & Dirty & Float \\
\hline 1992 & n.a & Dirty & Dirty/CP & Dirty & Dirty/CP \\
\hline 1993 & n.a & Fixed & Dirty/CP & Fixed & Float \\
\hline 1994 & n.a & Float & Fixed & Dirty/CP & Inconclusive \\
\hline 1995 & n.a & Float & Dirty & Dirty & Float \\
\hline 1996 & n.a & Fixed & Fixed & Dirty/CP & Float \\
\hline 1997 & n.a & Float & Dirty/CP & Float & Float \\
\hline 1998 & n.a & Float & Dirty/CP & Float & n.a \\
\hline 1999 & n.a & Float & Fixed & Fixed & n.a \\
\hline 2000 & n.a & Float & Fixed & Fixed & n.a \\
\hline 2001 & n.a & n.a & n.a & n.a & n.a \\
\hline
\end{tabular}

Source: Levy-Yeyati and Sturzenegger (2003)

The IMF's classification is published in the "Exchange Rate Arrangements" tables, included in various issues of the International Financial Statistics (IFS). It is based on member states' declarations and differs considerably from the de facto classifications (Table 6). The classifying method has been improved since 1999, to include more categories and also to take into account "de facto" management of the exchange rate. However, here, we consider the broad categories available on the whole period. 
Table 6: Exchange rate regimes, reported to the IMF

\begin{tabular}{|c|c|c|c|c|c|}
\hline & Thailand & Malaysia & India & Indonesia & Hong Kong \\
\hline 1990 & Pegged & Pegged & Floating & Intermediate & Pegged \\
\hline 1991 & Pegged & Pegged & Floating & Intermediate & Pegged \\
\hline 1992 & Pegged & Pegged & Intermediate & Intermediate & Pegged \\
\hline 1993 & Pegged & Intermediate & Floating & Intermediate & Pegged \\
\hline 1994 & Pegged & Intermediate & Floating & Intermediate & Pegged \\
\hline 1995 & Pegged & Intermediate & Floating & Intermediate & Pegged \\
\hline 1996 & Intermediate & Intermediate & Floating & Intermediate & Pegged \\
\hline 1997 & Intermediate & Intermediate & Floating & Floating & Pegged \\
\hline 1998 & Floating & Pegged & Floating & Floating & Pegged \\
\hline 1999 & Floating & Pegged & Floating & Floating & Pegged \\
\hline 2000 & Floating & Pegged & Floating & Floating & Pegged \\
\hline \multirow[t]{2}{*}{2001} & Floating & Pegged & Floating & Floating & Pegged \\
\hline & China & Philippines & South Korea & Singapore & Pakistan \\
\hline 1990 & Intermediate & Floating & Intermediate & Intermediate & Intermediate \\
\hline 1991 & Intermediate & Floating & Intermediate & Intermediate & Intermediate \\
\hline 1992 & Intermediate & Floating & Intermediate & Intermediate & Intermediate \\
\hline 1993 & Intermediate & Floating & Intermediate & Intermediate & Intermediate \\
\hline 1994 & Intermediate & Floating & Intermediate & Intermediate & Intermediate \\
\hline 1995 & Intermediate & Floating & Intermediate & Intermediate & Intermediate \\
\hline 1996 & Intermediate & Floating & Intermediate & Intermediate & Intermediate \\
\hline 1997 & Intermediate & Floating & Floating & Intermediate & Intermediate \\
\hline 1998 & Intermediate & Floating & Floating & Intermediate & Intermediate \\
\hline 1999 & Intermediate & Floating & Floating & Intermediate & Intermediate \\
\hline 2000 & Pegged & Floating & Floating & Intermediate & Intermediate \\
\hline 2001 & Pegged & Floating & Floating & Intermediate & Intermediate \\
\hline
\end{tabular}

Source: IMF, IFS.

As Levy-Yeyati and Sturzenegger (2003) point out, their classification and that of the IMF bear certain similarities. However, the IMF's classification, which is based on member states' announcements, tends to overestimate the number of pure floats. This discrepancy evidenced by Calvo and Reinhart (2002), can be ascribed to a "fear of floating". Furthermore, the IMF classification, like the LYS one, fails to take account of devaluations. This is a major drawback when assessing the macroeconomic impact of exchange rate regime, since such breaks are usually followed by sizeable recessions, as we will see in the next section.

Compared with the IMF classification, the results are fairly homogenous. Our classification subdivides "intermediate" regimes into crawling pegs and managed floats. Unsurprisingly, and as with the LYS method, we find more pegged systems than does the IMF. Thus, we are capturing situations where a de facto fixed exchange rate system is in place, but a float has been reported to the IMF. Also, by systematically detecting episodes of devaluation, our method offers a significant advantage for analysing the impact of these exchange rate regimes on macroeconomic performance. Table 7 compares the results obtained using the different approaches. 
Table 7: Comparison of results obtained by the three classification methods in the Asian sample, 1990-2000

\begin{tabular}{lccccc}
\hline & Float & Intermediate & Fixed & Inconclusive & Devaluation \\
\hline IMF & $30 \%$ & $47 \%$ & $23 \%$ & - & - \\
LYS & $24 \%$ & $37 \%$ & $33 \%$ & $6 \%$ & - \\
Our classification (1) & $15.2 \%$ & $34.5 \%$ & $39.6 \%$ & - & $10.6 \%$ \\
\hline
\end{tabular}

(1) calculated on the basis of the quarterly classification

Source: authors' calculations.

Table 7 provides telling evidence of the "fear of floating" brought to light by Calvo and Reinhart (2000). Far fewer floats are detected using the statistical approach than are reported to the IMF. We detect even fewer of them than the LYS approach does, because we take into account crawling pegs and devaluation. Our classification confirms the strong ties linking the Asian currencies to the dollar - almost $65 \%$ of the regimes are pegs or crawling pegs - which are often cited as one of the main causes behind the 1997-1998 crisis.

\subsection{Average performance by category}

Having classified observations by de facto regime, we are able to calculate average growth and inflation performance for each category (see table 8). However, the small number of floating exchange rates obtained in the classification does not allow to yield robust conclusions about them. As GDP growth is only available on a yearly basis, we use the yearly classification of table 4 , for calculating the average growth per currency regime 4 For inflation, we use the quarterly classification given in appendix.

One striking result is the monotonous relationship found between exchange rate flexibility and these macroeconomic variables. As the regime flexibility increases, average growth is higher and inflation lower. Regimes based on pure floats appear to achieve the highest growth over the sample, with average rates of $8.4 \%$, while pegs yield the best inflationary performances, with average inflation of $4.8 \%$ compared to $9.2 \%$ for floats. Intermediate regimes, crawling pegs and managed float achieve intermediate performances.

\footnotetext{
4

When two regimes are given for one year, we take the one which is also found in the previous year. When it is the case for both, we take the one that is also found in the following year.
} 
Table 8: Average annual GDP growth and inflation, by exchange rate regime

\begin{tabular}{lccc}
\hline & $\begin{array}{c}\text { GDP growth } \\
\text { Annual basis }\end{array}$ & $\begin{array}{c}\text { Inflation } \\
\text { Quarterly basis }\end{array}$ & $\begin{array}{c}\text { Number of observations } \\
\text { Annual/Quarterly }\end{array}$ \\
\hline Peg & $6.0 \%$ & $4.8 \%$ & $40 / 164$ \\
Crawl & $6.5 \%$ & $7.4 \%$ & $21 / 106$ \\
Managed & $6.0 \%$ & $7.5 \%$ & $2 / 37$ \\
Float & $8.4 \%$ & $9.2 . \%$ & $9 / 63$ \\
Devaluation & $2.2 \%$ & $8.4 \%$ & $32 / 44$ \\
\hline
\end{tabular}

Source : authors' calculations from IFS, IMF data

Devaluation periods recorded the lowest growth rates and a high rate of inflation. The first of these points is noteworthy. According to these results, far from providing an economic stimulus, devaluations seem to trigger recession. This may result from unhedged liabilities contracted by domestic agents. These negative consequences of devaluation explain the "fear of floating" highlighted by Calvo and Reinhart (2002). However, here, the results only concerns the simultaneous link between devaluation and growth, it does not preclude that lagged or long term effects could be positive.

These results on the averages for the different categories are nevertheless questionable, for they are subject to an assumption of ceteris paribus. To lift this assumption, we have to bring in other control variables by performing regressions.

\section{ECONOMETRIC ANALYSIS}

To determine the impact of the exchange rate regime on growth and inflation in the ten sample countries, we perform several regressions on panel data for the 10 countries over the 1990-2001 period. We measure the effect of the exchange rate regime on macroeconomic performance by inserting dummy variables representing them in the regression, as did Levy-Yeyati and Sturzenegger (2000). This method is also used to assess the impact of exchange rate regime on other variables, such as the degree of currency mismatch Arteta (2003), or the probability of crisis (Domaç and alii (2003).

The dummy variables of exchange rate regimes are directly deduced from the classification and constructed in the following way. The dummy $D_{i, t, q}^{k}$, represents the existence of an exchange rate regime of type $k$ ( $k=$ peg, crawling peg, managed float, float or devaluation) in country $i$ for the year $t$ and quarter $q$ :

$D_{i, t, q}^{k}=1$, when the country $i$ is classified in the regime $k$ in year $t$ and quarter $q i=$ $1 . .10, t=1990,2001, q=1, . .4, k=$ peg, crawling peg, managed float, float or devaluation(9)

$D_{i, t, q}^{k}=0$, otherwise 
In each regression, we use one of these regimes as the benchmark, so its dummy is taken out of the equation. The coefficients of the other dummy variables then measure the impact of a given regime relative to the benchmark.

\subsection{Impact on growth}

As GDP data are only available on an annual basis, the regression is made on a yearly basis, using yearly dummy variables for exchange rate regimes. For keeping the high degree of precision given by our quarterly classification, the yearly dummy variables for each exchange rate regimes are constructed by averaging the quarterly dummies described in (5) and (6).

$D_{i, t}^{k}=\frac{1}{4} \sum_{q=1}^{4} D_{i, t, q}^{k}$

This simply amounts to set the dummy $D_{i, t}^{k}$ equal to the number of quarters when the regime $\mathrm{k}$ has been implemented, divided by four.

$D_{i, t}^{k}=\frac{n}{4}$, when the country $i$ is classified in the regime $k$ during $n$ quarters of the year $t$,

$0 \leq n \leq 4$

$D_{i, t}^{k}=0$, otherwise

We also introduce in the regression control variables, which are supposed to act on longterm growth. These variables are based on endogenous growth models. They can be found in empirical studies of long-term growth, such as those by Barro (1991), Barro-Lee (1994), Razin-Collins (1997) and Levy-Yeyati-Sturzenegger (2001b). They are public spending on education (EDU), the growth rate of the total population (POP), the degree of openness (OPEN), the investment rate (INVEST) and the initial level of GDP per capita (GDP), which is designed to stand for the catching-up process.

The expected effects of the control variables are as follows. Education spending (EDU) should have a positive impact on growth, since such expenditure is generally viewed as an improvement in human capital. The population growth (POP) and the investment rate (INVEST) should also have a positive impact, insofar as they help to increase the factors of production. The likely effect of the openness variable (OPEN) is less clear-cut. However, given that most countries in our sample have based their development strategy on exports, a positive impact can be expected. The initial GDP per capita (GDP) variable should have a negative impact, if these countries do "catch up".

The series on growth and investment rates, exports, imports and GDP are taken from the IMF's International Financial Statistics database. The series for public education spending, population and GDP in purchasing power parity (PPP) come from the World Bank database (see the appendix for a description of all variables and sources). The openness ratio is calculated as the sum of exports and imports relative to GDP. The catchup variable (GDP) used is the GDP in PPP per capita in 1990. We consider the EDU, POP and INVEST variables to be constant for each country over the entire period because they 
are supposed to have only a long-term effect. They are fixed at their average value over the period and standardised with respect to the sample average.

As we do not expect short-term effect of exchange rate regime, the growth data are smoothed annually to remove cyclical effects. To do this, the average annual growth rate is calculated as the average of the growth rates recorded in the year in question, the previous year and the following year. Indeed, if exchange rate regimes affect economic growth, the effects will involve mechanisms, such as the credibility effect, that could reduce interest rate in the case of pegged exchange rate or better softening of business cycle, that could stabilise investment, for floating exchange rates. These effects will not be seen immediately. That is why we also introduce a lag of one year on all the explanatory variables. The managed float regime is used as the benchmark. The coefficients of the other regimes' dummy variables therefore measure the growth differential relative to the managed float.

The regression on Table 9 measures the impact of the different regimes on growth with a one-year lag. The control variables are significant, except the investment rate, which is removed from the regression. They all have their expected effect, except population.

According to these findings, episodes of fixed exchange rates generated markedly lower growth rates than did managed floats. In fact, pegs led to a $2.5 \%$ reduction in growth. This differential is significantly different from zero at a $10 \%$ level of significance. By contrast, growth under crawling peg and floating regimes was not different from that of managed floats. Their coefficients are not significantly different from zero. Devaluations have the most harmful effects on growth. The growth rate during such periods is $11.8 \%$ lower than that recorded under managed floats. This coefficient is significantly different from zero at a $1 \%$ level of significance.

These findings are consistent with the results of the average by exchange rate regime, made in the previous section, and also with those of Levy Yeyati and Sturzenegger(2001), that evidenced a weaker growth for fixed exchange rate regimes. Ghosh, Gulde, Ostry and Wolf (1997) also found a smaller growth for pegged exchange rate countries but their result was not significant. The findings on negative effects of devaluation on growth could be explained by the severity of the exchange rate crises in the sample. It is also consistent with the "fear of floating" evidenced by Calvo and Reinhart. As devaluation does not "pay", emerging countries have better to maintain their exchange rate. 
Table 9: GDP growth regression

Dependent variable: GDP growth

Method: Pooled Least Squares; Total panel observations 100

\begin{tabular}{lcccc}
\hline Variable & Coefficient & Std. Error & t-Statistic & Prob. \\
\hline Constant & 0.415 & 0.082 & 5.01 & 0.0000 \\
\hline Dummy PEG (-1) & -0.025 & 0.014 & -1.772 & 0.079 \\
\hline Dummy CRAWL (-1) & 0.007 & 0.014 & 0.50 & 0.614 \\
\hline Dummy FLOAT (-1) & -0.00004 & 0.016 & -0.149 & 0.9978 \\
\hline Dummy DEVALUATION (-1) & -0.118 & 0.027 & -4.38 & 0.0000 \\
\hline OPEN & 0.045 & 0.012 & 3.56 & 0.0005 \\
\hline GDP & -0.0419 & 0.010 & -4.05 & 0.0001 \\
\hline EDU & 0.027 & 0.012 & 2.19 & 0.0309 \\
\hline POP & -0.071 & 0.0168 & -4.21 & 0.0000 \\
\hline R-squared & 0.352 & Mean dependent variable & 0.051 \\
Adjusted R-squared & 0.295 & S.D. dependent variable & 0.042 \\
S.E. of regression & 0.035 & Sum squared residuals & 0.114 \\
F-statistic & 6.187 & Durbin-Watson statistic & 0.936 \\
Prob (F-statistic) & 0.000000 & & & \\
\hline & & &
\end{tabular}

\subsection{Endogeneity and growth}

It is possible to have a two-way causality between economic performance and the exchange rate regime. In other words, macroeconomic performance may be a function of the exchange rate regime, which is what we are testing here, but the reverse may also be true, i.e. economic conditions themselves may drive certain choices of exchange rate regimes. We only partly address this problem of uncertain causality in the previous section by introducing a lag of one year in the dummy variables in the regressions. Here, we investigate further this issue.

What would the reverse causality mean? This would imply that the monetary authorities choose the exchange rate regime according to the growth rate. This hypothesis is not justified by the economic literature on the subject. The empirical studies by Edwards (1996), Rizzo (1998), Poirson (2001), Juhn and Mauro (2002) and Bénassy-Quéré and Coeuré (2002) do not retain growth among the determinants of exchange rate regime. This variable is not present in the 14 studies on the subject reviewed by Juhn and Mauro (2002). Only the level of GDP is tested, for example by Edwards (1996), Rizzo (1998), Poirson (2001), Juhn and Mauro (2002) and also Alesina and Wagner (2003), in order to account for the size of the country; and also, the GDP per capita, standing for the level of development, which is anyway quite a different variable from the GDP growth. 
Nevertheless, we use the procedure of White (1984), which allows to address the problem of possible endogeneity of the exchange rate dummies and at the same time to correct problems of heteroscedasticity. This method consists in using an instrumental variable regression in order to obtain an estimated occurrence probability of each exchange rate regime.

In a first step, we make a multilogit, regressing the exchange rate dummies on explanatory instrumental variables. The explanatory variables are those supposed to explain the countries' exchange rate regime choice in the studies mentioned above. They are also taken from Levy-Yeyati and Sturzenegger (2001) and Arteta (2003), that tried to address the question of endogeneity on the same type of equations. Here, we retain the following variables: the openness ratio; the investment rate; the ratio of domestic credit to GDP; the ratio of quasi-money to money - these two latter variables measure the financial depth of the economy - and the ratio of initial reserves to GDP, which measures the capacity of the central bank to defend a fixed exchange rate. These variables are taken annually. The regression enables us to obtain the estimated probabilities of each regime, according to the characteristics of the country. In the second step, we make a new regression on growth where regime dummies are replaced by the estimated values of their probabilities.

Results, presented in table 10, confirm those of the first regression (table 9). Growth performances remain more limited for anchored than for floating regimes. As previously, pure floats do not seem to have generated significant differences in growth compared to managed floats. The only difference between the two regressions concerns crawling pegs, that seem here to have yield a lower growth than managed floats. For this second regression, the interpretation of the coefficients associated with each regime is not straightforward, since the dummies are now probabilities, always smaller than unity. 
Table 10: Comparative regressions on growth of GDP

\begin{tabular}{|c|c|c|c|}
\hline \multirow{2}{*}{$\begin{array}{l}\text { Dependent variable: } \\
\text { GDP growth } \\
\text { Constant }\end{array}$} & \multirow{2}{*}{$\begin{array}{c}\begin{array}{c}\text { Initial regression } \\
\text { Pooled Least Squares }\end{array} \\
0.415^{* * *} \\
(5.01)\end{array}$} & \multicolumn{2}{|c|}{$\begin{array}{c}\text { Two-step regression with } \\
\text { instrumental variables for dummies }\end{array}$} \\
\hline & & $\begin{array}{c}0.409 * * * \\
(4.29)\end{array}$ & \\
\hline Dummy PEG (-1) & $\begin{array}{l}-0.025^{*} \\
(-1.77)\end{array}$ & $\begin{array}{c}-0.210 * * \\
(-2.38)\end{array}$ & \\
\hline Dummy CRAWL(-1) & $\begin{array}{l}0.007 \\
(0.50)\end{array}$ & $\begin{array}{c}-0.355 * * * \\
(-2.97)\end{array}$ & \\
\hline Dummy FLOT(-1) & $\begin{array}{l}-0.00004 \\
(-0.0023)\end{array}$ & $\begin{array}{l}-0.0815 \\
(-0.779)\end{array}$ & \\
\hline Dummy DEV(-1) & $\begin{array}{c}-0.118 * * * \\
(-4.38)\end{array}$ & $\begin{array}{c}-0.029 * * * \\
(-3.64)\end{array}$ & \\
\hline POP & $\begin{array}{c}-0.071 * * * \\
(-4.21)\end{array}$ & $\begin{array}{c}-0.058 * * * \\
(-3.04)\end{array}$ & \\
\hline GDP & $\begin{array}{c}-0.041 * * * \\
(-4.05)\end{array}$ & $\begin{array}{c}-0.026^{* *} \\
(-2.18)\end{array}$ & \\
\hline OPEN & $\begin{array}{c}0.045 * * * \\
(3.56)\end{array}$ & $\begin{array}{l}0.030 \\
(1.25)\end{array}$ & \\
\hline EDU & $\begin{array}{c}0.027 * * \\
(2.19)\end{array}$ & $\begin{array}{c}0.044 * * \\
(2.45)\end{array}$ & \\
\hline$\overline{\operatorname{Res}}$ & ts of the instrumental $v$ & riables regression & \\
\hline R-squared & 0.430 & Mean dependent variable & 0.051 \\
\hline Adjusted R-squared & 0.380 & S.D. dependent variable & 0.042 \\
\hline S.E. of regression & 0.0335 & Sum squared residuals & 0.101 \\
\hline F-statistic & 8.5021 & Durbin-Watson statistic & 0.916 \\
\hline Prob (F-statistic) & 0.0000 & Panel observations 99 & \\
\hline
\end{tabular}

Note $: * * *, * * *$ stand for coefficients respectively $99 \%, 95 \%$ and $90 \%$ percent significantly differnet from zero. Figures in brackets are t-statistics.

\subsection{Impact on inflation}

Because inflation is more reactive than growth, we employ quarterly data to measure the impact of exchange rate regimes on inflation. Therefore, we use the quarterly dummy variables described in equations (9) and (10).

We start from the following model, where the inflation rate $\pi$ is a function of the logarithmic change in the money supply $\Delta m$, the growth in GDP $\triangle G D P$ and the interest rate $r$ :

$\pi=a \Delta m+\beta \Delta G D P+\gamma r$ 
We add to this equation the dummy variables for the exchange rate regimes. As growth is not available on a quarterly basis, it is the same smoothed annual variable, as previously replicated for each quarter.

The variables are expected to have the following effects. Changes in the money supply should have a positive impact on inflation (a positive), given that any increase in the money supply is likely to result in a price rise. GDP growth should have a positive impact ( $B$ positive), via a Phillips curve, assuming that high growth rates are likely to cause economic activity to heat up and wages and prices to rise. The impact of interest rates is harder to predict. In theory, a negative sign might be expected, since high interest rates signal a tight monetary policy that is likely to curb inflation by slowing activity and lowering investment. However, a reverse causal link is possible, through the central banks' reaction function, which responds to high inflation rates by hiking interest rates. This would also be consistent with a "Fisher" effect.

The data on inflation, changes in the money supply and interest rates are taken from the IMF's quarterly IFS database. We introduce a one-year lag for the peg dummy variable and a six-month lag for devaluations. Price inertia supplies the justification for these lags. Moreover, a peg is unlikely to cause inflation to abate immediately; rather the impact will be felt after a delay, through a decline in expected inflation as the peg gains in credibility. As for the growth regression, we use the managed float as the benchmark regime for this regression.

The regression on Table 11 measures the impact on inflation of different exchange rate arrangements. The control variables do have the expected effect. The findings demonstrate that fixed regimes were followed by lower inflation Pegs generated $1.5 \%$ lower inflation than managed float. This difference is significantly different from zero. On the contrary, pure floats were associated by an increase in inflation, estimated at $1.7 \%$. By contrast, crawling pegs showed no difference from a managed float in terms of inflation, as its coefficient was not significant. As expected, devaluations were followed by an upturn in inflation, which was $2.1 \%$ higher than that recorded by managed floats.

These results on inflation are consistent with the conclusions of Levy Yeyati and Sturzenegger (2001) and of Ghosh, Gulde, Ostry and Wolf (1997). However, Levy Yeyati and Sturzenegger(2001) made a distinction between "long peg" and "short peg" while showing the under-performance associated with "short peg" regimes. This latter category corresponds to the fixed exchange rates with frequent adjustments of parity in Ghosh and alii (1997). Here, we proceed by separating the periods of rupture of pegs and we identify them with the "devaluation" dummy. We find that pegs are associated with lower inflation, while devaluation has a large inflationary effect. Concerning pure floats, our results confirm those of Levy Yeyati and Sturzenegger (2001b) and of Ghosh and alii (1997), by showing that they are significantly more inflationary. 
Table 11: Inflation regression

Dependent variable: inflation rate

Method: Pooled Least Squares

Total panel observations 358, sample(adjusted): 1991:1 2000:4

\begin{tabular}{lcccc}
\hline Variable & Coefficient & Std. Error & t-statistic & Prob. \\
\hline Constant & -7.14 & 1.27 & -5.62 & 0.0000 \\
Dummy PEG(-4) & -1.468 & 0.71 & -2.04 & 0.0411 \\
Dummy CRAWL & 0.330 & 0.78 & 0.42 & 0.6747 \\
Dummy FLOAT & 1.70 & 0.91 & 1.87 & 0.0622 \\
Dummy DEVALUATION(-2) & 2.123 & 1.06 & 2.00 & 0.046 \\
\hline GDP growth & 0.137 & 0.07 & 1.97 & 0.0048 \\
Money growth? & 0.075 & 0.03 & 2.67 & 0.0078 \\
Interest rate & 1.021 & 0.07 & 13.6 & 0.0000 \\
R-squared & 0.48 & Mean dependent variable & 6.78 \\
Adjusted R-squared & 0.47 & S.D. dependent variable & 8.077 \\
S.E. of regression & 5.87 & Sum squared residuals & 12065.08 \\
Log likelihood & -817.34 & F-statistic & 46.51 \\
Durbin-Watson statistic & 0.354 & Prob(F-statistic) & 0.00000 \\
\hline
\end{tabular}

The findings of these regressions confirm the analysis of the previous section. In other words, fixed exchange rate regimes generated lower inflation, but at the price of weaker growth. Floating regimes had higher inflation, but not stronger growth. Overall, the intermediate regimes - managed floats and crawling pegs - appeared to achieve good results in terms of growth and inflation.

\subsection{Inflation and endogeneity}

We also try to address the issue of endogeneity of the exchange rate regime to inflation. A reverse causality in the inflation regression is more likely than for growth, as inflation may play a role in the choice of an exchange rate regime. Two effects are possible.

First, a country could choose a fixed exchange rate because he already has a low inflation. This makes the peg more sustainable, since it avoids the main drawback of pegs, which is the real exchange rate appreciation and subsequent loss of competitiveness. Poirson (2001) found this kind of effect in her cross-section regression on 93 countries for year 1999: the higher the inflation rate, the more likely is the adoption of a flexible regime. This sign was also found by Edwards (1996) and Rizzo (1998).

Second, the reverse mechanism could be true. A country could adopt a peg because of his high inflation, if he expects that the peg could bring more discipline and credibility to the government policy. This was clearly the case of countries like Argentina, Estonia, 
Lithuania and Bulgaria, when they adopted a currency board in the nineties. They did it because their inflation was so high, that they felt this was a drastic way to get rid of it. However, this kind of effect is not found in empirical studies. The reason may be that high inflation only plays a role at the time of implementing the peg and the regressions generally explain the exchange rate choice for a given period, regardless of when the changes of regimes occurred. If the peg succeeds in reducing inflation, the initial effect will disappear in a whole period regression; if the peg does not succeed in reducing inflation, it will certainly collapse soon, leaving only few periods for finding an econometric relation.

Possibly because of these contradictory effects, inflation is not found to be a significant variable for explaining the choice of an exchange rate regime by Juhn and Mauro (2002), and it is not retained in the multinomial model by Bénassy-Quéré and Coeuré (2002).

We tested for a possible endogeneity of exchange regime to inflation by using the same two step procedure described in 6.2. In the first step, the procedure consists in explaining the choice of the exchange rate regime in a multilogit model by economic fundamentals. This is very difficult to do on a quarterly periodicity, for it is very unlikely that this choice is made on a quarterly basis. When considering the effect of high inflation on a peg choice mentioned above, we see that countries only choose their exchange rate regimes according to the economics in given times of their history, and then they just try to stick to their choice, even if fundamentals have changed. In this situation, the choice is very difficult to explain on a time-series basis. That is why some authors, as Poirson (2001) or BénassyQuéré and Coeuré (2002) prefer to make the regression on a cross-section basis. This may explain our failure in this estimation. We tried the same explanatory variables as in 6.2 , adding the inflation rate. Not surprisingly, the variables were either non significant or wrongly signed. In the second step, the estimated probabilities of regimes were not significant in the regression of inflation.

We tried again by aggregating our quarterly data to yearly series. However, this trial was also not successful. Finally, we used the same occurrence probabilities estimated in section 6.2 on the growth in a yearly regression on inflation. In all cases, the results obtained did not reveal significant effect of exchange rate regimes dummies in the new regression. This is why we do not present these results here. Consequently, we cannot conclude that the effect of exchange rate regimes on inflation is not yielded by an endogeneity bias.

\section{CONCLUDING REMARKS}

This analysis brings light to bear on several interesting aspects of the de facto regimes followed by Asian countries in the 1990s and the linkage between these regimes and macroeconomic performance. By putting forward a new method of classifying countries by exchange rate regime, based on statistical observation, we avoid the pitfalls of the existing approaches and can thus trace accurately the presence of different regimes across the period. Like Calvo and Reinhart (2000), we found major discrepancies between what countries said they did in terms of their exchange rate policy and what they actually did. Our classification highlights the policy of pegging to the dollar that most Asian countries followed until the 1997 crisis. It also clearly demonstrates that the Asian countries loosened their exchange rate policies in the aftermath of the 1997 devaluations, which is consistent with the findings of Hernandez and Montiel (2001). 
The econometric results show that fixed exchange rate regimes are associated to better performances in terms of inflation. This confirms those of previous studies, as those of Levy Yeyati and Sturzenegger (2001) and of Ghosh and alii (1997). This result seems to appear here more clearly because, thanks to a quarterly classification, we are able to separate the periods of peg - which are associated with low inflation - from the ruptures of anchoring, which generally correspond to devaluations generating a strong inflationary effect. Nevertheless, we cannot exclude the hypothesis that this result is due to an endogeneity bias, by which countries with low inflation are more likely to choose a pegged exchange rate. The regressions also show that pegs dampened GDP growth, compared to managed floats. This result is shown to persist after correcting for endogeneity. Furthermore, pegs are sometimes followed by severe devaluation, which causes growth to collapse, in the concerned countries.

Floating regimes are shown to be linked to higher inflation, but fail to generate higher growth than intermediate systems. Therefore, intermediate regimes - the managed float and the crawling peg -appear to be reasonable options: they yield the highest GDP growth and are associated with intermediate results in terms of inflation. These results are consistent with those of Williamson (2000), who found that intermediate arrangements were the most suitable for emerging economies. 


\section{BIBLIOGRAPHY}

Alesina, A. and A. Wagner (2003), "Choosing (and reneging) exchange rate regimes", NBER Working paper 9809.

Arteta, C. (2003), “Exchange rate regimes and financial dollarization: Does flexibility reduce currency mismatches in bank intermediation? ", Board of Governors of the Federal Reserve System, International Finance Discussion Papers n ${ }^{\circ} 738$.

Auernheimer, L. and S. Georges (2000), "Bad dreams under alternative anchors; are the consequences different?”, IMF Working Paper WP/00/120.

Barro, R. (1991), "Economic Growth in a Cross-Section of Countries", Quarterly Journal of Economics 16, p 406-443.

Barro, R. and J. Wa Lee (1994), "Sources of Economic Growth", Carnegie-Rochester Conference Series on Public Policy 40, p1-46.

Bénassy-Quéré, A. (1996), "Régimes et politiques de change en Asie", Economie Internationale no. 66.

Bénassy-Quéré, A. and B. Coeuré (2000), "Big and small currencies: the regional connection", Document de travail CEPII n²000-10.

Bénassy-Quéré, A. and B. Coeuré (2002), “The survival of intermediate exchange rate regimes ", CEPII, Document de travail 2002-07.

Bénassy-Quéré, A. and B. Coeuré (2003), “ On the identification of de facto currency pegs ", mimeo.

Bordo, M., Eichengreen, B., Klingebiel, D. and Martinez Peria, M.S. (2001), "Is the crisis problem growing more severe?", Economic Policy 31, 51-82.

Bubula, A. and I. Ötker-Robe (2002), "The evolution of exchange rate regimes since 1990: evidence from de facto pegs", IMF Working Paper WP/2002/155.

Calvo, G. and C. Reinhart (2000), “Fixing for your life.", NBER, Working Paper No. 8006.

Calvo, G. and and C. Reinhart (2002), “Fear of floating ”, Quarterly Journal of Economics 117, pp. 379-408.

Calvo, G. and F. Mishkin (2003), “ The mirage of exchange rate regimes for emerging countries ", NBER, Working Paper No. 9808.

Coudert, V. (2004), "Exchange rate Regimes and Crises: are Fixed Exchange Rates Really to Blame?, " Working Paper CEPN, forthcoming, University of Paris 13, http://www.univ-paris13.fr/cepn.htm, also available in French : «Régimes de change et crises: Les taux de change fixes sont-ils injustement suspectés?”, in R. Boyer, M. 
Dehove and D. Plihon : "Les crises financières, analyses et propositions", rapport du Conseil d'Analyse Economique, à paraître, juillet 2004.

Domaç, I. and M. Soledad Martinez Peria (2003), “Banking crises and exchange rate regimes: is there a link? ”, Journal of International Economics 61, pp. 41-72.

Dornbusch, R. (2001), “ Fewer monies, better monies ”, NBER,Working paper No. 8324.

Edwards, S. (1996), "The determinants of the choice between fixed and flexibleexchangerate regimes," NBER Working Paper, No. 5756.

Eichengreen, B. and P. Masson Paul (2000), "Exit strategies: Policy options for countries seeking greater exchange rate flexibility”, IMF Occasional Paper, no. 168.

Fischer, S. (2001), "Exchange rate regimes: is the bipolar view correct?", Lecture on Economics in Government, American Economic Association Meeting, New Orleans.

Frankel, J.A. and Wei S.J. (1993), "Trade Blocs and Currency Blocs", in NBER Working Paper no. 4335.

Frankel, J., S. Schmukler and L. Serven (2000), "Verifiability and the vanishing intermediate exchange rate regime", NBER Working Paper No. 4901.

Frankel, J. (1999), "No single currency regime is right for all countries or at all times", NBER Working Paper No. 7338.

Ghosh A., A.-M. Gulde, J. Ostry and H. Wolf (1997), “Does the nominal exchange rate regime matter?", NBER, Working Paper 5874.

Hausmann, R., M. Gavin, C. Pages-Serra and E. Stein (1999), “Financial Turmoil and the Choice of Exchange rate regime ", Inter-American Development Bank, WORKING PAPER $n^{\circ} 400$.

Hernandez, L. and P.J. Montiel P.J. (2001), "Post-crisis exchange rate policy in five Asian countries: filling in the 'hollow middle', mimeo.

Juhn, G. and P. Mauro (2002), "Long-Run Determinants of Exchange Rate Regimes: A Simple Sensitivity Analysis", IMF Working Paper WP/02/104.

Lahiri, A. and C. Végh (2001), "Living with the Fear of Floating: An Optimal Policy Perspective", NBER Working Paper No..

Lambert, F., C. Rebillard and J. Vierling (2002), "Quel régime de change pour les pays émergents, étude empirique sur les pays d'Amérique latine”, mimeo, ENSAE working group steered by V. Coudert.

Levy Yeyati, E. and F. Sturzenegger (2000), “ Classifying Exchange rate regimes: Deeds versus Words ", mimeo, Universidad Torcuato di Tella, forthcoming in European Economic Review. 
Levy Yeyati, E. and F. Sturzenegger (2001), "Exchange Rate Regimes and Economic Performance ", IMF, Staff papers, vol 47.

Levy Yeyati E. and F. Sturzenegger (2003), “A de facto Classification of Exchange Rate Regimes: A Methodological Note,” American Economic Review, Vol. 93, No. 4.

Masson, P. (2000), "Exchange rate regime transitions" Journal of Development Economics, Vol 64, pp 571-586.

Obsfeld, M. and K. Rogoff, (1995), “The mirage of fixed exchange rates ", NBER Working Paper No. 5191.

Miotti, L. D. Plihon and C. Quenan (2001), “The euro and financial relations between Latin America and Europe: medium- and long-term implications", mimeo, CEPAL, United Nations.

Poirson, H. (2001), “How do countries choose their exchange rate regime?”, IMF Working Paper WP/01/46.

Popper, H. and J. Lowell (1994), "Officially Floating, Implicitly Targeted Exchange Rates: Examples from the Pacific Basin" in R. Glick and M. Hutchison, eds., Exchange Rate Policy and Interdependence: Perspectives from the Pacific Basin, Cambridge University Press.

Razin, O. and S. Collins (1997), "Real exchange rate misalignment and growth", NBER Working Paper No. 6174.

Reinhart, C. (2000), “The mirage of floating exchange rates”, American Economic Review, May 2000.

Reinhart, C. and K. Rogoff (2002), “The Modern History of Exchange Rate Arrangements A Reinterpretation", NBER Working Paper 8963, June 2002, forthcoming in Quarterly Journal of Economics.

Rizzo, J.-M. (1998), "The economic determinants of the choice of an exchange rate regime: a probit analysis," Economics Letters, 59, No. 3, 283-287.

Rogoff, K., A. Husain and A. Mody, R. Brooks, N. Oomes (2003), “ Evolution and Performance of Exchange Rate Regimes ”, IMF Working Paper, WP/2003/243.

Von Hagen, J. and J. Zhou (2004), The Choice of Exchange Rate Regime in Developing Countries: A Multinational Panel Analysis CEPR Discussion Paper No. 4227

White, H. (1984), Asymptotic Theory for Econometricians, Academic Press, New York.

Wickam, P. (2002), "Do flexible exchange rates of developing countries behave like the floating exchange rates of industrialized countries?", IMF Working Paper. 
Does Exchange Rate Regime Explain Differences in Economic Results for Asian Countries?

Williamson, J. (2000), "Exchange Rate Regimes for Emerging Markets Reviving the Intermediate Option", Institute for International Economics, Policy Analyses in International Economics 60. 


\section{Appendix 1}

\section{Classification of de facto exchange rate regimes:}

Sample period: 1990-2001.

Countries: China, South Korea, Hong Kong, India, Indonesia, Malaysia, Pakistan, Philippines, Singapore and Thailand.

Benchmark sample for the floating regime: Germany, UK and Japan.

Exchange rate series: weekly series taken from the Datastream base.

Reserves: series taken from the IFS base (1LDZF series)

Growth regression:

Dependent variable: GDP growth rate at constant prices calculated as the change in real GDP at constant 1995 prices. Source: IFS (99BVPZF series).

Control variables:

- Education spending (DPE): average ratio of education spending to GDP over the period, standardised with respect to the sample average. Source: World Bank.

- Total population (POP): average growth rate of the total population over the period, standardised with respect to the sample average. Source: World Bank.

- Investment (INVEST): average ratio of GFCF to GDP over the period, standardised with respect to the sample average. Source: IFS (99BZF and 93EZF series).

- Openness (OP): average ratio of the sum of imports and exports to GDP over the period. Source: IFS (70ZF, 71ZF and 99BZF series).

- Catch-up (GDP): GDP PPP per capita in 1990 for each country considered. Source: World Bank.

$\underline{\text { Inflation regression: }}$

Dependent variable: inflation, measured by the growth rate of consumer prices. Source: IFS (64ZF series).

Control variables:

- GDP growth rate at constant prices: change in real GDP at constant 1995 prices. Source: IFS (99BVPZF series).

- $\quad$ Change in the money supply. Source: IFS (34XZF series).

- Interest rate. Source: IFS (60PZF series). 

Appendix 2: Results of the classification of de facto exchange rate regimes

\begin{tabular}{|c|c|c|c|c|c|c|c|c|c|c|}
\hline & Thailand & Malaysia & Philippines & China & Indonesia & India & Korea & Singapore & Hong Kong & Pakistan \\
\hline 1990:1 & Float & Peg & N/A & N/A & N/A & Crawl & Crawl & Float & Peg & Crawl \\
\hline 1990:2 & Float & Peg & N/A & N/A & N/A & Crawl & Crawl & Float & Peg & Crawl \\
\hline 1990:3 & Float & Peg & N/A & N/A & N/A & Crawl & Crawl & Float & Peg & Crawl \\
\hline 1990:4 & Float & Peg & N/A & N/A & N/A & Crawl & Crawl & Float & Peg & Crawl \\
\hline 1991:1 & Peg & Peg & N/A & N/A & N/A & Devaluation & Crawl & Float & Peg & Crawl \\
\hline 1991:2 & Peg & Peg & N/A & N/A & N/A & Devaluation & Crawl & Float & Peg & Crawl \\
\hline 1991:3 & Peg & Peg & N/A & N/A & N/A & Managed & Crawl & Float & Peg & Crawl \\
\hline 1991:4 & Peg & Peg & N/A & N/A & N/A & Managed & Crawl & Float & Peg & Crawl \\
\hline 1992:1 & Peg & Float & Float & $\mathrm{N} / \mathrm{A}$ & Crawl & Devaluation & Crawl & Peg & Peg & Crawl \\
\hline 1992:2 & Peg & Float & Devaluation & Devaluation & Crawl & Crawl & Crawl & Peg & Peg & Crawl \\
\hline 1992:3 & Peg & Float & Float & N/A & Crawl & Crawl & Crawl & Peg & Peg & Crawl \\
\hline 1992:4 & Peg & Float & Float & Devaluation & Crawl & Crawl & Crawl & Peg & Peg & Crawl \\
\hline 1993:1 & Peg & Peg & Crawl & Devaluation & Crawl & Devaluation & Crawl & Float & Peg & Crawl \\
\hline 1993:2 & Peg & Peg & Float & Crawl & Crawl & Crawl & Crawl & Float & Peg & Managed \\
\hline 1993:3 & Peg & Peg & Crawl & Float & Crawl & Crawl & Crawl & Float & Peg & Devaluation \\
\hline 1993:4 & Peg & Peg & Float & Crawl & Crawl & Crawl & Crawl & Float & Peg & Managed \\
\hline 1994:1 & Peg & Managed & Float & Float & Crawl & Peg & Float & Float & Peg & Peg \\
\hline 1994:2 & Peg & Managed & Managed & Managed & Crawl & Peg & Float & Float & Peg & Peg \\
\hline 1994:3 & Peg & Managed & Managed & Managed & Crawl & Peg & Float & Float & Peg & Peg \\
\hline 1994:4 & Peg & Managed & Managed & Float & Crawl & Peg & Float & Float & Peg & Peg \\
\hline 1995:1 & Peg & Managed & Devaluation & Peg & Crawl & Crawl & Peg & Peg & Peg & Crawl \\
\hline 1995:2 & Peg & Peg & Managed & Peg & Crawl & Crawl & Peg & Peg & Peg & Crawl \\
\hline 1995:3 & Peg & Peg & Crawl & Peg & Crawl & Devaluation & Peg & Peg & Peg & Crawl \\
\hline 1995:4 & Peg & Peg & Crawl & Peg & Crawl & Managed & Peg & $\mathrm{Peg}$ & Peg & Devaluation \\
\hline
\end{tabular}


Does Exchange Rate Regime Explain Differences in Economic Results for Asian Countries?

\begin{tabular}{|c|c|c|c|c|c|c|c|c|c|c|}
\hline & Thailand & Malaysia & Philippines & China & Indonesia & India & Korea & Singapore & $\begin{array}{l}\text { Hong } \\
\text { Kong }\end{array}$ & Pakistan \\
\hline 1996:1 & Peg & Peg & Peg & Peg & Peg & Float & Float & Peg & Peg & Managed \\
\hline 1996:2 & Peg & Peg & Peg & Peg & Peg & Float & Float & Peg & Peg & Managed \\
\hline 1996:3 & $\mathrm{Peg}$ & Peg & $\mathrm{Peg}$ & $\mathrm{Peg}$ & $\mathrm{Peg}$ & $\mathrm{Peg}$ & Crawl & Peg & $\mathrm{Peg}$ & Managed \\
\hline 1996:4 & Peg & Peg & Peg & Peg & Peg & Peg & Crawl & Peg & Peg & Devaluation \\
\hline 1997:1 & Managed & Managed & Managed & Peg & Float & Crawl & Crawl & Crawl & Peg & Crawl \\
\hline 1997:2 & Managed & Managed & Managed & Peg & Managed & Crawl & Managed & Crawl & Peg & Crawl \\
\hline 1997:3 & Devaluation & Devaluation & Devaluation & Peg & Devaluation & Crawl & Managed & Devaluation & Peg & Crawl \\
\hline 1997:4 & Devaluation & Devaluation & Devaluation & Peg & Devaluation & Devaluation & Devaluation & Devaluation & Peg & Devaluation \\
\hline 1998:1 & Managed & Managed & Managed & Peg & Devaluation & Managed & Managed & Managed & Peg & Managed \\
\hline 1998:2 & Devaluation & Devaluation & Devaluation & Peg & Devaluation & Devaluation & Managed & Devaluation & Peg & Managed \\
\hline 1998:3 & Float & Float & Devaluation & Peg & Float & Crawl & Devaluation & Peg & Peg & Devaluation \\
\hline 1998:4 & Float & Float & Float & Peg & Float & Crawl & Float & Peg & Peg & Float \\
\hline 1999:1 & Crawl & Peg & Crawl & Peg & Devaluation & Crawl & Peg & Peg & Peg & Crawl \\
\hline 1999:2 & Float & Peg & Float & Peg & Float & Crawl & Peg & Peg & Peg & Float \\
\hline 1999:3 & Devaluation & Peg & Devaluation & Peg & Devaluation & Crawl & $\mathrm{Peg}$ & Peg & $\mathrm{Peg}$ & Crawl \\
\hline 1999:4 & Float & Peg & Crawl & Peg & Float & Crawl & $\mathrm{Peg}$ & Peg & Peg & Crawl \\
\hline 2000:1 & Crawl & Peg & Float & Peg & Float & Crawl & Crawl & Crawl & Peg & Crawl \\
\hline $2000: 2$ & Crawl & Peg & Crawl & $\mathrm{Peg}$ & Devaluation & Crawl & Crawl & Crawl & Peg & Crawl \\
\hline 2000:3 & Crawl & Peg & Crawl & Peg & Float & Crawl & Crawl & Crawl & $\mathrm{Peg}$ & Devaluation \\
\hline $2000: 4$ & Float & Peg & Float & Peg & Devaluation & Crawl & Devaluation & Crawl & Peg & Managed \\
\hline 2001:1 & Float & Peg & Float & Peg & Devaluation & Crawl & Float & Crawl & $\mathrm{Peg}$ & Crawl \\
\hline 2001:2 & Crawl & Peg & Float & Peg & Float & Crawl & Float & Crawl & Peg & Managed \\
\hline 2001:3 & Crawl & Peg & Managed & Peg & Float & Crawl & Peg & Float & Peg & Crawl \\
\hline 2001:4 & Crawl & Peg & Crawl & Peg & Managed & Crawl & Float & Crawl & Peg & Managed \\
\hline
\end{tabular}




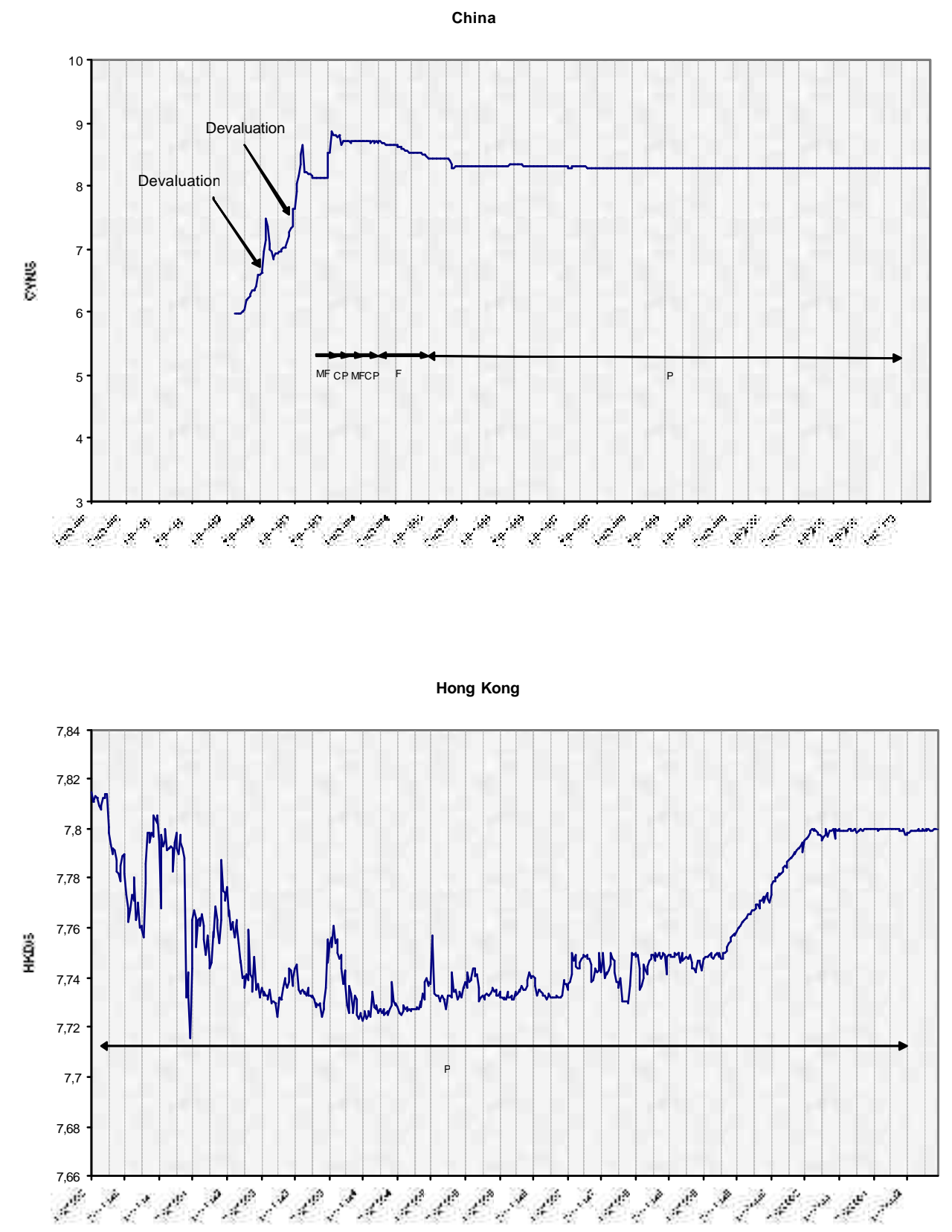


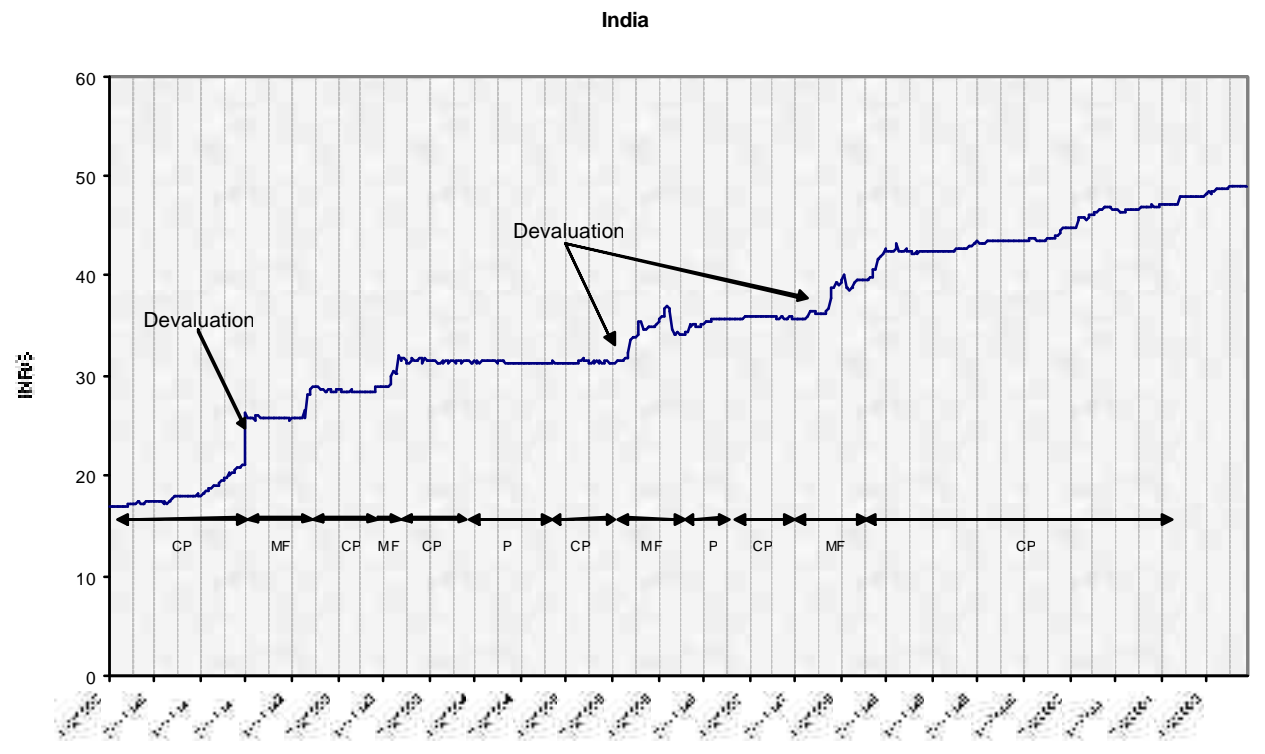

Indonesia

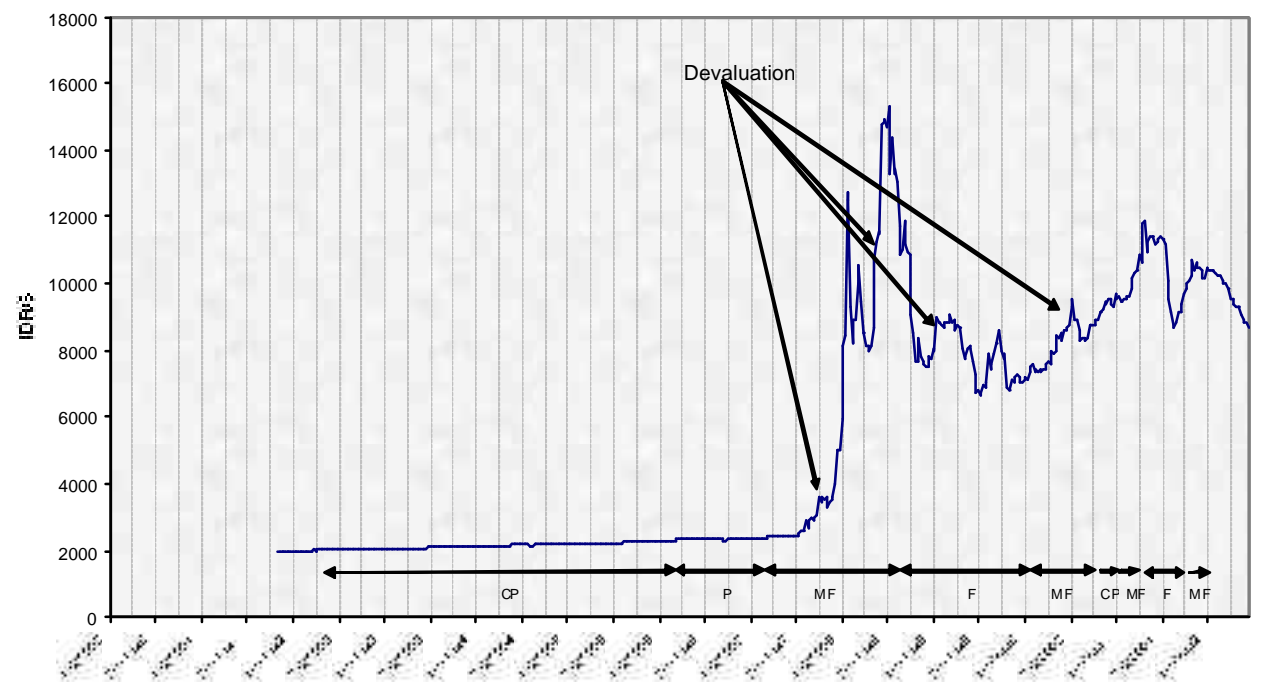


Does Exchange Rate Regime Explain Differences in Economic Results for Asian Countries?
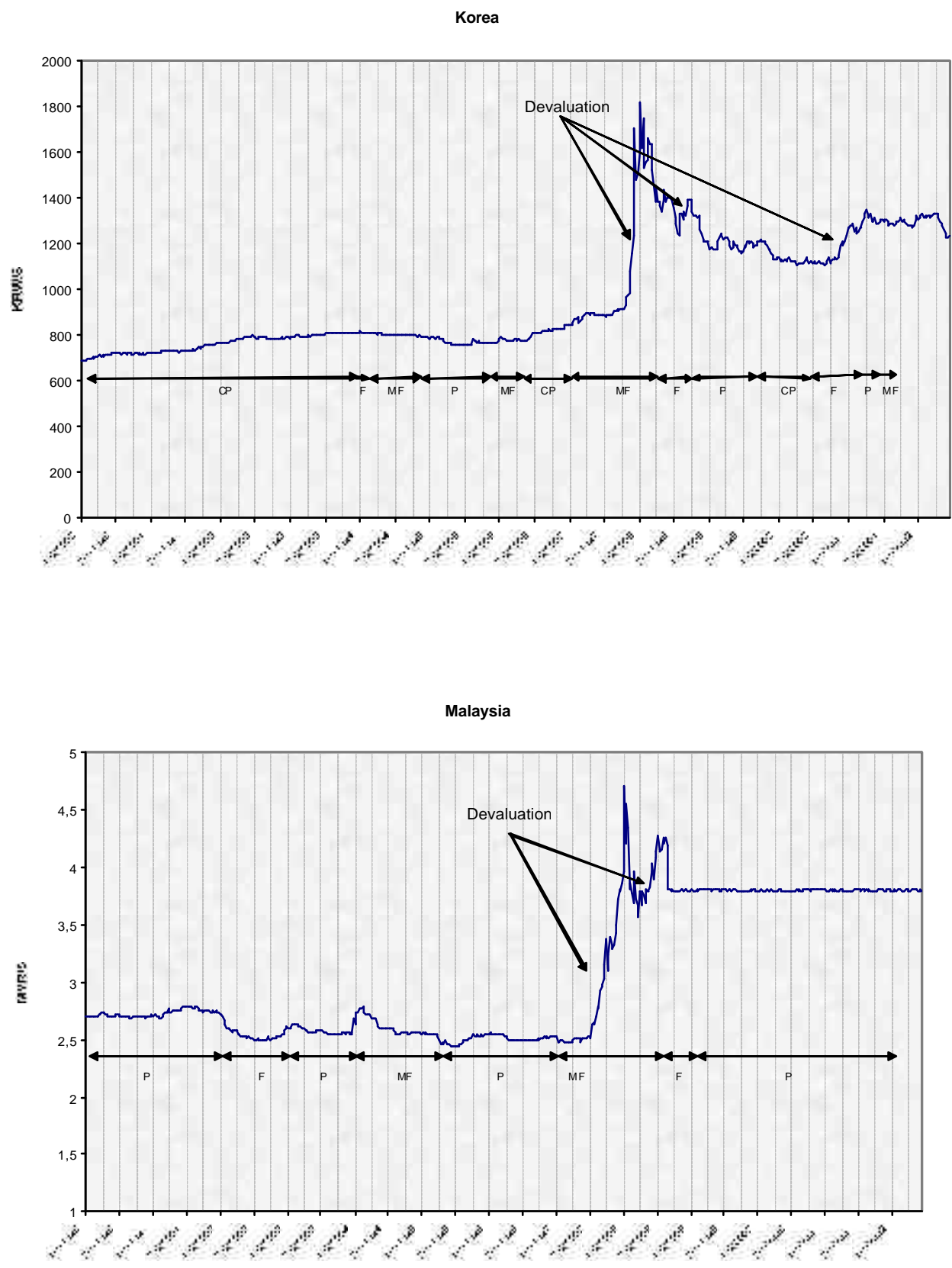

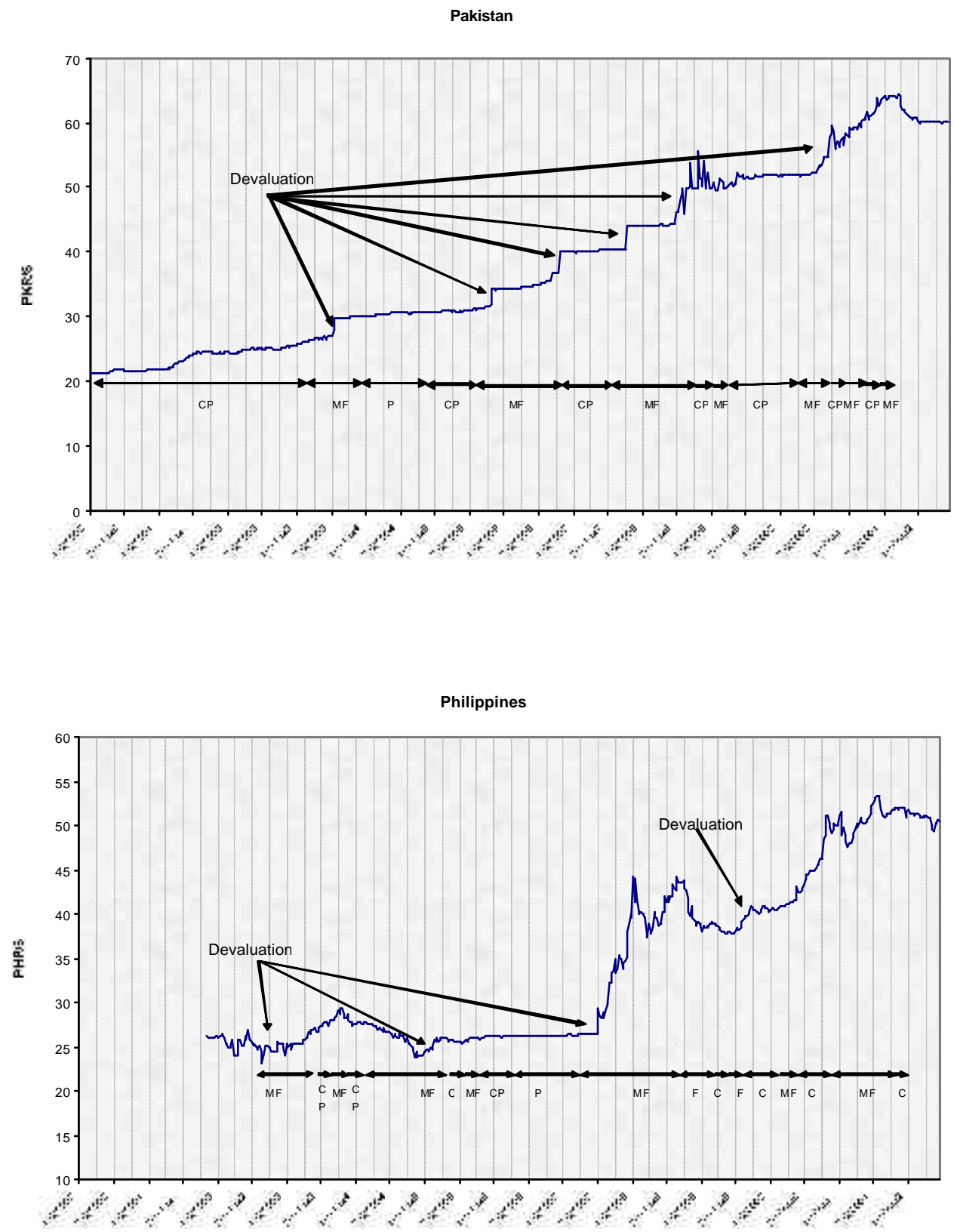
Does Exchange Rate Regime Explain Differences in Economic Results for Asian Countries?
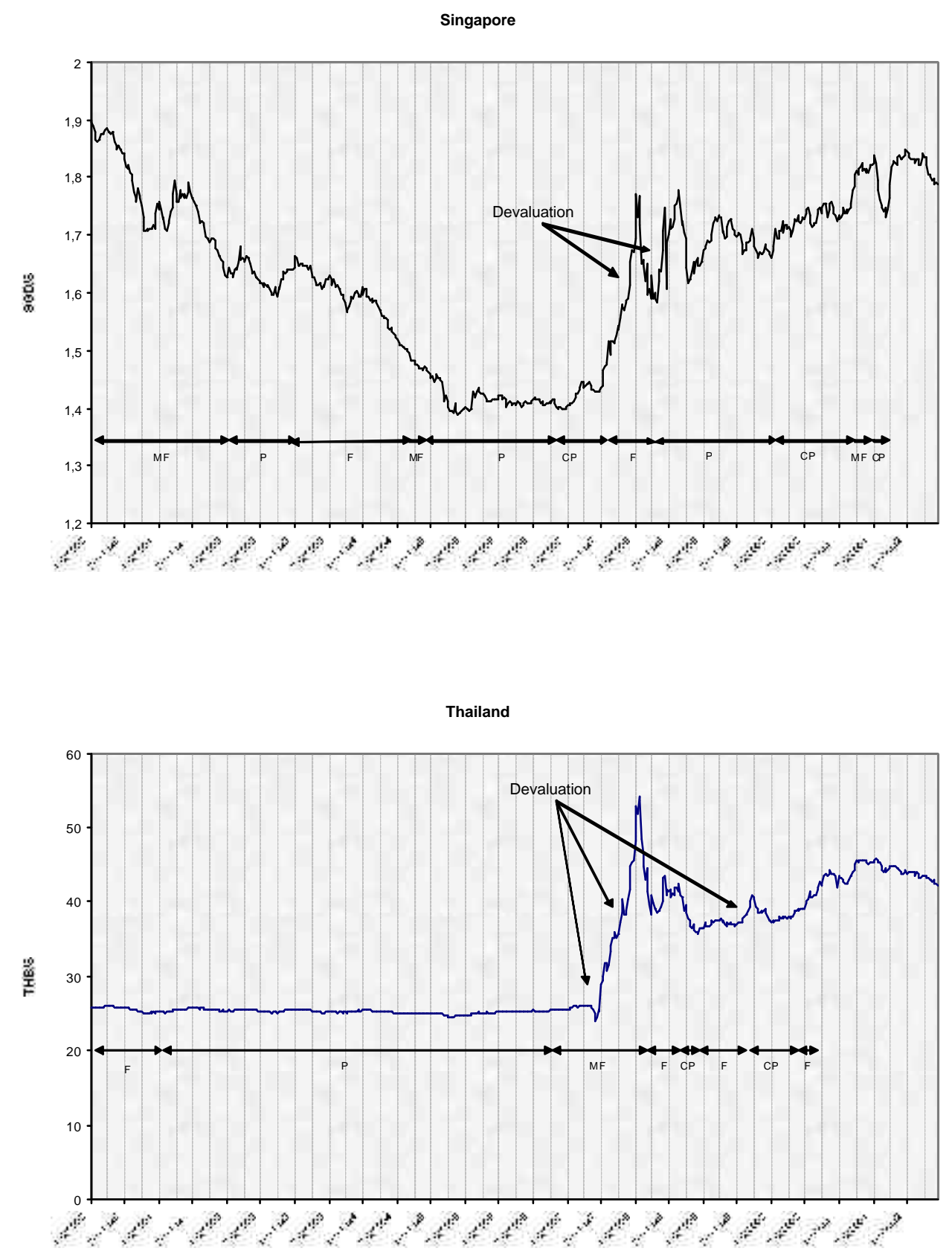


\section{LIST OF WORKING PAPERS RELEASED BY CEPII}

No

2004-04 Trade in the Triad: How Easy is the Access to Large Markets
Authors

L. Fontagné, T. Mayer \& S. Zignago

H. Boulhol

P. Villa

A. Banerjee \& P.

Zanghieri

A. Bénassy-Quéré \&

A. Lahrèche-Révil

J. Francois, H. Van Meijl,

F. Van Tongeren

N. Kousnetzoff

B. Rzepkowski

A. Bénassy-Quéré, L. Fontagné \& A. Lahrèche-Révil

F. Lemoine \& D. Ünal-Kesenci

K. Head \& T. Mayer

F. Legros

C. Disdier \& T. Mayer

L. Fontagné, J.L.

2003-12 Market Access Liberalisation in the Doha Round:

\footnotetext{
5 Working papers are circulated free of charge as far as stocks are available; thank you to send your request to CEPII, Sylvie Hurion, 9, rue Georges-Pitard, 75015 Paris, or by fax : (33) 0153685504 or by e-mail Hurion@cepii.fr. Also available on: Ilwww.cepii.fr. Working papers with* are out of print. They can nevertheless be consulted and downloaded from this website. 5

Les documents de travail sont diffusés gratuitement sur demande dans la mesure des stocks disponibles. Merci d'adresser votre demande au CEPII, Sylvie Hurion, 9, rue Georges-Pitard, 75015 Paris, ou par fax : (33) 0153685504 ou par e-mail Hurion@cepii.fr. Egalement disponibles sur : Ilwww.cepii.fr. Les documents de travail comportant* sont épuisés. Ils sont toutefois consultable sur le web CEPII.
} 
Scenarios and Assessment

2003-11 On the Adequacy of Monetary Arrangements in SubSaharian Africa

2003-10 The Impact of EU Enlargement on Member States : a CGE Approach

2003-09 India and the World Economy: Traditional Specialisations and Technology Niches

2003-08 Imination Amongst Exchange-Rate Forecasters : Evidence from Survey Data

2003-07 Le Currency Board à travers l'expérience de l'Argentine

2003-06 Trade and Convergence : Revisiting Ben-David

2003-05 Estimating the Fundamental Equilibrium ExchangeRate of Central and Eastern European Countries the EMU Enlargement Perspective

2003-04 Skills, Technology and Growth is ICT the Key to Success

2003-03 L'investissement en TIC aux Etats-Unis et dans quelques pays européens

2003-02 Can Business and Social Networks Explain the Border Effect Puzzle?

2003-01 Hyperinflation and the Reconstruction of a National Money: Argentina and Brazil, 1990-2002

2002-18 Programme de travail du CEPII pour 2003

2002-17 MIRAGE, a Computable General Equilibrium Model for Trade Policy Analysis

2002-16 Evolutions démographiques et marché du travail : des liens complexes et parfois contradictoires

2002-15 Exchange Rate Regimes and Sustainable Parities for CEECs in the Run-up to EMU Membership

2002-14 When are Structural Deficits Good Policies?

2002-13 Projections démographiques de quelques pays de l'Union Européenne (Allemagne, France, Italie, Royaume-Uni, Pays-Bas, Suède)

2002-12 Regional Trade Integration in Southern Africa
Guérin \& S. Jean

A. Bénassy-Quéré \& Maylis Coupet

H. Bchir, L. Fontagné \& P. Zanghieri

S. Chauvin \& F. Lemoine

M. Beine,

A. Bénassy-Quéré \&

H. Colas

S. Chauvin \& P. Villa

G. Gaulier

B Egert \&

A. Lahrèche-Revil

J. Melka, L. Nayman, S. Signano \& N. Mulder

G. Cette \& P.A. Noual P.P. Combes, M. Lafourcade \& T. Mayer J. Sgard

M.H. Bchir, Y. Decreux,

J.L. Guérin \& S. Jean

L. Cadiou, J. Genet \&

J.L. Guérin

V. Coudert \&

C. Couharde

J. Chateau

R. Sleiman

S. Chauvin \& G. Gaulier 
2002-11 Demographic Evolutions and Unemployment: an Analysis of French Labour Market with Workers Generations

2002-10 Liquidité et passage de la valeur

2002-09 Le concept de coût d'usage Putty-Clay des biens durables

2002-08 Mondialisation et régionalisation : le cas des industries du textile et de l'habillement

2002-07 The Survival of Intermediate Exchange Rate Regimes

2002-06 Pensions and Savings in a Monetary Union: An Analysis of Capital Flow

2002-05 Brazil and Mexico's Manufacturing Performance in International Perspective, 1970-1999

2002-04 The Impact of Central Bank Intervention on Exchange-Rate Forecast Heterogeneity

2002-04 The Impact of Central Bank Intervention on Forecast Heterogeneity

2002-03 Impacts économiques et sociaux de l'élargissement pour l'Union européenne et la France

2002-02 China in the International Segmentation of Production Processes

2002-01 Illusory Border Effects: Distance Mismeasurement Inflates Estimates of Home Bias in Trade

2001-22 Programme de travail du CEPII pour 2002

2001-21 Croissance économique mondiale: un scénario de référence à l'horizon 2030

2001-20 The Fiscal Stabilization Policy under EMU - An Empirical Assessment

2001-19 Direct Foreign Investments and Productivity Growth in Hungarian Firms, 1992-1999

2001-18 Market Access Maps: A Bilateral and Disaggregated Measure of Market Access

2001-17 Macroeconomic Consequences of Pension Reforms in Europe: An Investigation with the INGENUE World Model
J. Château, J.L. Guérin \& F. Legros

P. Villa

M.G. Foggea \& P. Villa

M. Fouquin, P. Morand R. Avisse G. Minvielle \& P. Dumont

A. Bénassy-Quéré \& B. Coeuré

A. Jousten \& F. Legros

N. Mulder, S. Montout \& L. Peres Lopes

M. Beine,

A. Benassy-Quéré,

E. Dauchy \&

R. MacDonald

M. Beine,

A. Benassy-Quéré,

E. Dauchi \&

R. MacDonald

M.H. Bchir \&

M. Maurel

F. Lemoine \&

D. Ünal-Kesenci

K Head \& T. Mayer

N. Kousnetzoff

A. Kadareja

J. Sgard

A. Bouët, L. Fontagné, M. Mimouni \& X. Pichot

Equipe Ingénue 
2001-16* La productivité des industries méditerranéennes

2001-15 Marmotte: A Multinational Model

2001-14 The French-German Productivity Comparison Revisited: Ten Years After the German Unification

2001-13* The Nature of Specialization Matters for Growth: An Empirical Investigation

2001-12 Forum Economique Franco-Allemand - DeutschFranzösisches Wirtschaftspolitisches Forum, Political Economy of the Nice Treaty: Rebalancing the EU Council and the Future of European Agricultural Policies, $9^{\text {th }}$ meeting, Paris, June $26^{\text {th }} 2001$

2001-11 Sector Sensitivity to Exchange Rate Fluctuations

2001-10* A First Assessment of Environment-Related Trade Barriers

2001-09 International Trade and Rend Sharing in Developed and Developing Countries

2001-08 Economie de la transition : le dossier

2001-07 Exit Options for Argentina with a Special Focus on Their Impact on External Trade

2001-06 Effet frontière, intégration économique et 'Forteresse Europe'

2001-05 Forum Économique Franco-Allemand - DeutschFranzösisches Wirtschaftspolitisches Forum, The Impact of Eastern Enlargement on EU-Labour Markets and Pensions Reforms between Economic and Political Problems, $8^{\text {th }}$ meeting, Paris, January 16 2001

2001-04 Discrimination commerciale : une mesure à partir des flux bilatéraux

2001-03* Heterogeneous Expectations, Currency Options and the Euro/Dollar Exchange Rate
A. Chevallier \&

D. Ünal-Kesenci

L. Cadiou, S. Dees,

S. Guichard,

A. Kadareja,

J.P. Laffargue \&

B. Rzepkowski

L. Nayman \&

D. Ünal-Kesenci

I. Bensidoun,

G. Gaulier

\& D. Ünal-Kesenci

M. Fouquin, K. Sekkat,

J. Malek Mansour,

N. Mulder \&

L. Nayman

L. Fontagné, F. von

Kirchbach \&

M. Mimouni

L. Fontagné \&

D. Mirza

G. Wild

S. Chauvin

T. Mayer

G. Gaulier

B. Rzepkowski 
2001-02 Defining Consumption Behavior in a Multi-Country Model

2001-01 Pouvoir prédictif de la volatilité implicite dans le prix des options de change

2000-22 Forum Economique Franco-Allemand - DeutschFranzösisches Wirtschaftspolitisches Forum, Trade Rules and Global Governance: A long Term Agenda and The Future of Banking in Europe, $7^{\text {th }}$ meeting, Paris, July 3-4 2000

2000-21 The Wage Curve: the Lessons of an Estimation Over a Panel of Countries

2000-20 A Computational General Equilibrium Model with Vintage Capital

2000-19 Consumption Habit and Equity Premium in the G7 Countries

2000-18 Capital Stock and Productivity in French Transport: An International Comparison

2000-17 Programme de travail 2001

2000-16 La gestion des crises de liquidité internationale : logique de faillite, prêteur en dernier ressort et conditionnalité

2000-15 La mesure des protections commerciales nationales

2000-14 The Convergence of Automobile Prices in the European Union: An Empirical Analysis for the Period 1993-1999

2000-13* International Trade and Firms' Heterogeneity Under Monopolistic Competition

2000-12 Syndrome, miracle, modèle polder et autres spécificités néerlandaises : quels enseignements pour l'emploi en France?

2000-11 FDI and the Opening Up of China's Economy

2000-10 Big and Small Currencies: The Regional Connection

2000-09* Structural Changes in Asia And Growth Prospects After the Crisis

2000-08 The International Monetary Fund and the International Financial Architecture

2000-07 The Effect of International Trade on Labour-Demand Elasticities: Intersectoral Matters
O. Allais, L. Cadiou \&

S. Dées

B. Rzepkowski

S. Guichard \& J.P. Laffargue

L. Cadiou, S. Dées \& J.P. Laffargue

O. Allais, L. Cadiou \& S. Dées

B. Chane Kune \& N. Mulder

J. Sgard

A. Bouët

G. Gaulier \& S. Haller

S. Jean

S. Jean

F. Lemoine

A. Bénassy-Quéré \&

B. Coeuré

J.C. Berthélemy \&

S. Chauvin

M. Aglietta

S. Jean 
2000-06 Foreign Direct Investment and the Prospects for Tax Co-Ordination in Europe

2000-05 Forum Economique Franco-Allemand - DeutschFranzösisches Wirtschaftspolitisches Forum, Economic Growth in Europe Entering a New Area?/The First Year of EMU, $6^{\text {th }}$ meeting, Bonn, January 17-18, 2000

2000-04* The Expectations of Hong Kong Dollar Devaluation and their Determinants

2000-03 What Drove Relative Wages in France? Structural Decomposition Analysis in a General

Equilibrium Framework, 1970-1992

2000-02 Le passage des retraites de la répartition à la capitalisation obligatoire : des simulations à l'aide d'une maquette

2000-01* Rapport d'activité 1999

1999-16 Exchange Rate Strategies in the Competition for Attracting FDI

1999-15 Groupe d'échanges et de réflexion sur la Caspienne. Recueil des comptes-rendus de réunion (déc. 97- oct. 98)"

1999-14 The Impact of Foreign Exchange Interventions: New Evidence from FIGARCH Estimations

1999-13 Forum Economique Franco-Allemand - DeutschFranzösisches Wirtschaftspolitisches Forum, Reduction of Working Time/Eastward Enlargment of the European Union, $5^{\text {th }}$ meeting, Paris, July 6-7 1999

1999-12* A Lender of Last Resort for Europe

1999-11* La diversité des marchés du travail en Europe: Quelles conséquences pour l'Union Monétaire; Deuxième partie: Les implications macroéconomiques de la diversité des marchés du travail

1999-10* La diversité des marchés du travail en Europe: Quelles conséquences pour l'Union Monétaire; Première partie : La diversité des marchés du travail dans les pays de l'Union Européenne

1999-09 The Role of External Variables in the Chinese Economy; Simulations from a macroeconometric
M. Aglietta

A. Bénéssy-Quéré, L. Fontagné \& A. Lahrèche-Révil

B. Rzepkowski

S. Jean \& O. Bontout

O. Rouguet \& P. Villa

A. Bénassy-Quéré, L. Fontagné \& A. Lahrèche-Révil

D. Pianelli \&

G. Sokoloff

M. Beine,

A. Bénassy-Quéré \&

C. Lecourt

L. Cadiou, S. Guichard \& M. Maurel

L. Cadiou \&

S. Guichard

S. Dees 
model of China

1999-08 Haute technologie et échelles de qualité : de fortes asymétries en Europe

L. Fontagné, M. Freudenberg \&

D. Ünal-Kesenci

1999-07 The Role of Capital Accumultion, Adjustment and Structural Change for Economic Take-Off: Empirical Evidence from African Growth Episodes

J.C. Berthélemy \&

L. Söderling

1999-06 Enterprise Adjustment and the Role of Bank Credit in Russia: Evidence from a 420 Firm's Qualitative Survey

S. Brana, M. Maurel \& J. Sgard

1999-05 Central and Eastern European Countries in the International Division of Labour in Europe

M. Freudenberg \& F. Lemoine

1999-04 Forum Economique Franco-Allemand - Economic Policy Coordination $-4^{\text {th }}$ meeting, Bonn, January 11121999

1999-03 Models of Exchange Rate Expectations: Heterogeneous Evidence From Panel Data

A. Bénassy-Quéré, S. Larribeau \& R. MacDonald

1999-02 Forum Economique Franco-Allemand - Labour Market \& Tax Policy in the EMU

1999-01 Programme de travail 1999 



\section{CEPII \\ DOCUMENTS DE TRAVAIL / WORKING PAPERS}

Si vous souhaitez recevoir des Documents de travail, merci de remplir le coupon-réponse ci-joint et de le retourner à :

Should you wish to receive copies of the CEPII's Working papers, just fill the reply card and return it to:

Sylvie HURION - Publications

CEPII - 9, rue Georges-Pitard - 75740 Paris - Fax : (33) 1.53.68.55.04

M./Mme / Mr./Mrs

Nom-Prénom / Name-First name

Titre / Title

Service / Department

Organisme / Organisation

Adresse / Address

Ville \& CP / City \& post code

Pays / Country... Tél.

Désire recevoir les Document de travail du CEPII $\mathrm{n}^{\circ}$ :

Wish to receive the CEPII's Working Papers No:

Souhaite être placé sur la liste de diffusion permanente (pour les bibliothèques)

Wish to be placed on the standing mailing list(for Libraries). 